\title{
O FIM DO (JUS)POSITIVISMO?
}

\author{
THE END OF (JUS)POSITIVISM
}

\section{Iago Moura Melo}

\begin{abstract}
Doutorando em Letras pela Universidade Estadual de Santa Cruz (UESC). Mestre em Letras (UESC). Bacharel em Direito (UESC) e Advogado (OAB/BA). É membro do Grupo de Estudos Discursivos (GED/UESC), do Grupo de Estudos Pecheutianos (GEP) e do Coletivo Contradit (Coletivo de Trabalho - Discurso e Transformação). Bolsista da Coordenação de Aperfeiçoamento de Pessoal de Nível Superior (CAPES).

E-mail: iagomouram@gmail.com
\end{abstract}

\section{Rick Afonso-Rocha}

Doutoranda e mestra pelo PPGL: Linguagens e Representações, da Universidade Estadual de Santa Cruz (PPGL/UESC). Bolsista da FAPESB. Integrante do grupo de pesquisa "O Espaço Biográfico no Horizonte da Literatura Homoerótica" (GPBIOH), do Núcleo de Estudos Queer e Decoloniais da UFRPE (NuQueer) e do Grupo de Pesquisa Estudos Literários Contemporâneos: Fontes da Literatura de Jornal da UEFS. Colaboradora do Grupo de

Estudos Discursivos em Arte e Design (NEDAD/UFPR), do Grupo de Estudos Discursivos da UESC (GED) e do blog Resista! Observatório de Resistências Plurais. E-mail: rickwhoop22@gmail.com

Recebido em: 20/04/2019

Aprovado em: 28/08/2019

RESUMO: Este trabalho explora as possibilidades de ser do (jus)positivismo, a partir de um enfoque fenomenológico-hermenêutico. Visa a perquirir uma resposta ativa ao problema formulado por Streck, no locus da jurisdição constitucional, que questiona as condições de possibilidade do positivismo jurídico diante do fenômeno da virada linguística. Pergunta-se se se trata efetivamente do fim do (jus)positivismo ou se a doutrina fenomenológico-existencial do direito traduziria uma expressão mais autêntica daquele modo de pensar, a partir de uma reflexão sobre a polissemia da palavra fim. Objetiva, assim, constatar que, com a aludida viragem, o deslocamento, na linguagem, da relação epistemológica sujeito-objeto para a relação hermenêutica sujeito-sujeito, e sobretudo com o recurso aos estudos de Martin Heidegger, a justeoria passa a habitar um novo lugar, que se cumpre na pesquisa fenomenológica pelo justo concreto, enquanto proposta hermenêutica. O fenômeno jurídico, tido sob os horizontes de uma ontologia fundamental, encontra o seu fim, isto é, tem-lhe descortinado, ao revés de seu término, um novo lugar e uma nova finalidade. A pergunta pelo que o direito é, instada pela fenomenologia existencial, permite que se inaugure um novo modo de ser do juspositivismo, que indaga sobre o jurídico posto não como o ser em sua totalidade, mas como fenômeno. Em última instância, constata-se a inauguração um novo telos para a justeoria, que poderá traduzir a revisão de um projeto prévio compreensivo subjetivista. Em sentido amplo, emprega o método especulativo-hermenêutico. Administra o método antropofágico, como proposto por Oswald de Andrade. Utiliza a técnica bibliográfica, desde um enfoque exploratório.

Palavras-chave: Discurso jurídico. Pesquisa pelo justo. Des-velamento. 
ABSTRACT: This work explores the possibilities of being from (jus) positivism, from a phenomenological-hermeneutic approach. It seeks to find an active response to the problem formulated by Streck at the locus of constitutional jurisdiction, which questions the conditions of possibility of legal positivism in face of the linguistic turn. It is questioned if it is effectively the end of (jus) positivism or whether the phenomenological-existential doctrine of law would translate a more authentic expression of that way of thinking, based on a reflection on the polysemy of the word end. It aims, therefore, to verify that, with the aforementioned approach, the displacement, in the language, of the subject-object epistemological relation to the hermeneutic subject-subject relation, and especially with the use of Martin Heidegger's studies, jus-theory begins to inhabit a new place, which is fulfilled in phenomenological research by the concrete, as a hermeneutic proposal. The juridical phenomenon, under the horizons of a fundamental ontology, finds its end, in other words, it has revealed to it, in reverse of its termination, a new place and a new purpose. The question of what law is, urged by existential phenomenology, allows the inauguration of a new way of being of jus-positivism, which inquiries about the legal position not as being in its totality, but as a phenomenon. Ultimately, the inauguration is a new telos for jus-theory, which may translate the revision of a comprehensive, but subjectivist project. Broadly, it uses the speculativehermeneutic method; it administers the anthropophagic method, as proposed by Oswald de Andrade. It uses the bibliographical technique, from an exploratory approach.

Keywords: Legal discourse. Search for justice. Un-veiling.

SUMÁRIO: Introdução; 1. Um museu de grandes novidades; 1.1. O tridimensionalismo jurídico de Miguel Reale; 1.2. O positivismo formalista de Hans Kelsen e o ideal metafísico de pureza; 1.3. Ronald Dworkin e a compreensão moral do direito; 2. A Ek-Sistentia, o lugar e a finalidade; 2.1. Da Ek-sistentia; 2.2. Do Lugar; 2.3. Da Finalidade; Considerações finais; Referências.

\section{INTRODUÇÃO}

Reflete-se sobre os lugares pelos quais passa a jusfilosofia brasileira na contemporaneidade, tendo em vista o devir com que se constroem os fundamentos dos saberes do/no direito. Acusa-se, desse modo, a impossibilidade de esses saberes se condensarem unicamente em um lugar inicial ou final. A fluidez do fenômeno jurídico e o redimensionamento cada vez mais constante de seus predicados apontam a insuficiência de construções assertóricas, responsáveis por preconizar onde começa e onde termina o jurídico mesmo. Por isso, este trabalho se lança numa reflexão sobre os lugares contemporâneos em que se pode seguir a jusfilosofia, tendo como questão o sentido e o lugar do juspotivismo no Brasil e tendo em conta a pertinência desse debate para a discussão em torno da jurisdição constitucional.

São três os discursos jusfilosóficos principais na contemporaneidade, cf. Mascaro (2014). De uma parte, a filosofia marxista do direito investiga, em linhas gerais, os nexos históricos e estruturais do direito com a sociedade. Essa corrente objetiva potencializar a transformação social, desde o direito, a política e a economia. De outra parte, desponta o juspositivismo, enquanto discurso tendente à legitimação e à aceitação do direito posto e das instituições a ele atinentes. $\mathrm{O}$ juspotivismo fraciona-se, conforme maior ou menor abertura epistemológico-teórica, em três desdobramentos específicos, a saber: juspositivismos ecléticos, juspositivismos estritos e juspositivismos éticos. Há que se falar, ainda, a respeito de uma terceira vertente na filosofia do direito. Segundo essa doutrina, o direito passa a ser compreendido em seu ser. Trata-se do que se pode denominar, lato sensu, de filosofia existencial do direito, cuja ascendência remonta às reflexões de Martin Heidegger. A abordagem que segue se traduz numa aposta de aproximação das duas últimas vertentes jusfilosóficas, como se verá. 
Pretende-se explorar as possibilidades de ser do juspositivismo, a partir de um enfoque fenomenológico-hermenêutico. Empreende-se, portanto, uma reflexão sobre o ser não como um ente, como fez a tradição filosófica e, consequentemente, jusfilosófica, mas a partir do construto heideggeriano da diferença ontológica ser-ente. O ente consubstancia tudo o que se presenta e se dá à sensibilidade, enquanto que o ser, conceito mais universal e mais concreto, e, por isso, insuscetível de definição (HEIDEGGER, 2012), é a própria presença do ente, tomada em seu (des)velamento. $\mathrm{O}$ que se mostra pode se velar. Trata-se do movimento da verdade, destituída de sua acepção tradicional como veritas (adequação entre linguagem e realidade, ou entre intelecto e coisa), que passa a ser compreendida como A-letheia, isto é, enquanto (des)velamento, como propõe Heidegger. Impõe-se, assim, uma ontologia fundamental, que preserve a diferença ser-ente. O ente se presenta, i. é, desvela-se enquanto tal, quando a sua presença está recuada, no velamento da clareira. Mas Heidegger (2012) ressalta que ontologia só pode ser pensada como fenomenologia ${ }^{1}$, já que o ser se mostra como fenômeno, isto é, como possibilidade do que é, a partir de si mesmo. O fenômeno é, então, aquilo que se mostra em si mesmo, como possibilidade de um ser que se mostra, ao passo que se oculta. A fenomenologia será o caminho para que aquilo que se mostra como sendo o que é possa vir a partir de si mesmo. Às coisas mesmas!

Incorpora-se, no nível epistemológico, a relação ser-ser, já que a relação sujeito-objeto não reponde mais aos reclames da totalidade daquilo que é, em razão de promover a cisão eumundo. Trata-se do que se pode chamar de virada linguístico-pragmática, ou ainda viragem ontológico-linguística, já que a “[...] linguagem, de terceira coisa, de mero instrumento e veículo de conceitos, passa a ser condição de possibilidade”. (STRECK, 2010, p. 163). Há o deslocamento da relação transcendental sujeito-objeto para o problema hermenêutico sujeito-sujeito no âmbito do conhecimento, com a consequente refutação dos paradigmas metafísicos objetivista (aristotélico-tomista) e subjetivista (filosofia da consciência). A justeoria, dessa maneira, passa a habitar um novo lugar na senda do pensamento, além tender a uma nova finalidade. O ser-a $i^{2}$ pode se reconciliar com o mundo, a partir de seu modo de ser autêntico, isto é, sendo-no-mundo (in-derWelt-sein) e com-o-outro (Mitsein). Assim se expressará uma compreensão do fenômeno jurídico que se paute nos pressupostos da ontologia fundamental. O direito passa a ser indagado em seu ser, de maneira que pode ser traduzido em possibilidades autênticas e inautênticas. Se a metafísica dos entes passa a ser questionada desde sua base historiográfica, de modo que filosofia se tornou sinônimo de esquecimento do ser, uma compreensão ontológica mesma do direito poderá deixar ver que a tradição jusfilosófica pensou o direito de modo essencialista, entificando-o, tal como fez a Filosofia com a questão do sentido do ser.

O juspositivismo, enquanto doutrina jusfilosófica, consolidou-se nos esteios dessa mesma tradição de encobrimento da questão do sentido do ser. Tal doutrina é, em nossa leitura, a que mais se presenta na prática e teoria jurídicas contemporâneas. O ser do direito passou a ser tido como sinônimo do direito posto. O ente "texto legislativo" passou a figurar como ser do jurídico, em prejuízo da diferença ontológica ser-ente. O fenômeno de entificação do ser jurídico foi, então, experimentado a partir de diferentes modos de ser, traduzindo juspositivismos ecléticos, estritos e

\footnotetext{
${ }^{1}$ Opta-se, neste trabalho, pela noção de fenomenologia que se extrai dos estudos de Heidegger, embora não se ignore o seu emprego por Kant, em sua Crítica da Razão Pura, ao demarcar os limites entre razão e sensibilidade, além de seu uso por Hegel, em sua Fenomenologia do espírito, para quem a expressão conduzia à dialética de síntese sujeitoobjeto. Não se olvida, ademais, da carga semântica que o termo fenomenologia possui, sobretudo, nos estudos de seu precursor mais recente, Edmund Husserl (1995), para quem essa atitude epistemológica traduziu um método transcendental que visava o alcance da "consciência pura", enquanto consciência intencional, isto é, enquanto consciência de alguma coisa, pondo entre parênteses os juízos existenciais, sob a égide do mundo-da-vida (LebensWelt).

${ }^{2}$ Conforme Lima (2015), a tradução do termo Dasein como "pre-sença”, feita por Márcia de Sá Cavalcante Schuback, na edição de Ser e tempo, da editora Vozes, é equivocada. Heidegger, de acordo com as traduções franceses, prefere a tradução "ser-o-aí" (être-le-là). Neste trabalho, opta-se pela utilização do termo ser-aí, bem como pelo emprego do original em alemão, em alguns momentos.
} 
éticos. Entretanto, pensar o que ficara oculto na experiência histórica de des-velamento do fenômeno jurídico, enquanto direito positivo, poderá traduzir uma nova possibilidade compreensiva desse ser jurídico, além de permitir uma constatação jusfilosófica de valor hermenêutico-existencial. A história dos juspotivismos torna-se um museu de grandes novidades. Do mesmo modo que a esfinge sofocleana se dirige a Édipo (SÓFOCLES, 1989), a complexidade social sentencia ao fenômeno jurídico: decifra-me ou te devoro! Entre a morte e a ressignificação, entre o fim, o lugar e a finalidade, emerge o destino do fenômeno jurídico como decisivo para a ek-sistencia ${ }^{3}$ do povo brasileiro. Diante desse momento existencial, ecoa profundamente a pergunta formulada por Streck (2010) a respeito do juspositivismo, tendo, como horizonte, o fenômeno da virada linguística

Parece não haver dúvida de que o positivismo - compreendido lato sensu (ou seja, as diversas facetas do positivismo) - não conseguiu aceitar a viragem interpretativa ocorrida na filosofia do direito (invasão da filosofia pela linguagem) e suas conseqüências [sic] no plano da doutrina e da jurisprudência. Se isto é verdadeiro - e penso que é - a pergunta que cabe é: como é possível continuar a sustentar o positivismo nesta quadra da história? (STRECK, 2010, p. 159, grifo nosso).

Este trabalho resulta de uma compreensão responsiva ativa, nos termos de Bakhtin $(1992)^{4}$, da pergunta instada por Streck, refletida sob o horizonte da situação ek-sistencial do povo brasileiro, conforme as formulações teóricas de Pereira e Maman. São, assim, em decorrência dessa compreensão, duas as questões que se põem. Como questão principal, indaga-se: o juspositivismo, a partir da experiência instada pela virada linguístico-pragmática, é conduzido ao seu fim? E, como questão satélite, pergunta-se: seria possível interpretar a doutrina fenomenológico-existencial do direito como um modo ser autêntico de juspositivismo, a partir do deslocamento semântico da palavra fim, para os sentidos de lugar e finalidade? É o que se pretende deixar ver com este trabalho.

Em sentido lato, segue-se, como orientação epistemológica, o caminho especulativohermenêutico. Esse método (caminho) se cumpre a partir da articulação da pesquisa na estrutura binária da verdade, como (des)velamento, de acordo com Stein, cf. aduz Pereira (1980a). Desse modo, refuta-se, neste trabalho, o monismo metódico muito afeito ao ideal moderno e prometeico de verdade objetiva. A verdade, enquanto construção interpretativa, dá-se sempre sob a égide do vivido, de modo que a conjugação de diferentes métodos de pesquisa se afigura como mais autêntica para que se forme um pensamento complexo e menos parcial. Administra-se o método antropofágico, tendo em vista que "Só a antropofagia nos une. Socialmente. Economicamente. Philosophicamente. (...) Tupy or not tupy, that is the question." (ANDRADE, 1976). Assim, os resultados compreensivos obtidos ao longo da pesquisa são subsumidos à brasilidade cognoscitiva dos pesquisadores, que almejam extrair deles resultados relevantes do ponto de vista de seu locus

\footnotetext{
${ }^{3}$ Neste trabalho, rejeita-se a noção metafísica de existentia, o que, conforme Heidegger (2005), promove a interiorização do ek-sistente, que, isolado, realiza um projeto inautêntico. Nesse sentido são às críticas de Heidegger ao emprego do termo aludido por Sartre, que conduziria a um humanismo ao modo da tradição. Heidegger propõe o emprego do termo ek-sistentia, já que, originariamente, o homem ek-siste, isto é, está fora-de-si, vazio de essência, lançando-se num projeto autêntico em que, sendo si mesmo, é-com-o-outro-no-mundo. Dito de outro modo, preservase o caráter ekstático do ser-aí. Só o homem ek-siste, enquanto que os demais entes, que ele não é, são ao modo da essência.

${ }^{4}$ Para Bakhtin (1992), a linguagem deixa de ser tida como mero instrumento comunicativo para se constituir como um espaço material de interação verbal, isto é, enquanto enunciado. Para o pensador russo, os falantes inscritos na dialética do discurso não devem ser tidos como sujeitos passivos no processo de interação verbal. Não há, assim, um interlocutor conformado na posição de ouvinte. Em suma, cedo ou tarde, um discurso que é enunciado responde nos discursos subsequentes e nos comportamentos de seus interlocutores ulteriores à enunciação, isto é, repercute no todo que é o enunciado. Esta pesquisa, assim, é um elo na cadeia da comunicação discursiva.
} 
epistemológico-espiritual. Por essa razão, busca-se, na justeoria brasileira, elementos para se pensar um novo modo de ser do juspositivismo. Embora haja algum recurso ao pensamento europeu, toda importação realizada é deglutida e adaptada à situação ek-sistencial do povo brasileiro, tomada como critério epistemológico. Utilizou-se a técnica bibliográfica, desde um enfoque exploratório, para a consulta da literatura.

A relevância prática e pertinência social desta pesquisa decorrem do movimento teórico aqui pretendido, já que, conforme elucida Eco (1996, p. 56), o caráter teórico de uma tese não se opõe e não se abstrai ao seu caráter político, pois "[...] todo trabalho científico, na medida em que contribui para o desenvolvimento do conhecimento alheio, tem sempre um valor político-positivo." Chama-se a comunidade jurídica ao despertamento de seu senso comum teórico (WARAT, 1982), que assinala a sua pobreza de pensamentos (HEIDEGGER, 2001). Objetiva-se a ocorrência de compreensões responsivas ativas a partir da interpretação deste trabalho como um ato de interação verbal (BAKHTIN, 1992).

\section{UM MUSEU DE GRANDES NOVIDADES ${ }^{5}$}

Tem-se, com o juspositivismo eclético, que desponta como teoria de afirmação do direito estatal positivo, de referenciais extra-normativos, a marca da suposta morte do jusracionalismo burguês do século XVIII. Nesse momento da vida do direito, elege-se como mais expressiva a proposta tridimensionalista de Miguel Reale, embora bastante posterior ao período histórico, em razão de expressar a doutrina eclética mais emblemática. Em seguida, no século XX, a pretensão de um uso estritamente técnico-normativo do direito torna-se responsável por ensejar o juspositivismo estrito, doutrina que recorre ao lastro teórico da filosofia analítica da linguagem, de referenciais lógicos. O positivismo-formalista de Hans Kelsen traduzirá a mais sofisticada forma de juspositivismo estrito. Ao fim do século XX, o juspositivismo pleno vivencia um profundo desgaste, como "má teoria do direito" que é, cf. terminologia de Dworkin (2002). Esse desgaste será responsável por autorizar, na vida do direito, uma nova visão de mundo, a que se denominou de juspositivismo ético, como será visto a seguir.

\subsection{O tridimensionalismo jurídico de Miguel Reale}

Se a doutrina do jusnaturalismo foi, de muito, alimentada por inspirações burguesas e de uma estética de conformação de expectativas, então, o juspositivismo do século XIX, que representou uma reorientação simbólica daquele modo de pensar, sob a forma normativo-estatal, não alçou a emancipação de tais inspirações. Trata-se, portanto, de uma continuidade filosófica, metodológica e epistemológica, no Direito, nada obstante se verificar uma descontinuidade histórica no que concerne à tomada do poder estatal por parte da burguesia emergente. A doutrina do ecletismo edificou-se sob os argumentos racionalistas do jusnaturalismo do século XVIII. Embora o fenômeno jurídico tenha passado a ser tido desde uma perspectiva normativa e estatal, no que respeita à elaboração ontológica, em nível de fundamentos, a seu turno, manteve-se o discurso metafísico do direito natural. O ente, portanto, afigura-se bastante presente, sendo sempre pressuposto como se fosse o ser, na ideia, no sujeito ou no valor.

Como uma espécie de continuação à Escola Histórica do Direito, liderada por Savigny, mas com expressividade muito superior, têm-se as doutrinas tridimensionais do direito. Miguel Reale (1992) implementa uma revisão dessas múltiplas formulações tricotômicas, e que, portanto, traduzem juspositivismos ecléticos ${ }^{6}$. Entretanto, este subitem não se aterá a uma proposta

\footnotetext{
${ }^{5}$ Faz-se alusão à composição de Arnaldo Brandão, O tempo não para.

${ }^{6}$ Citem-se como representantes da justeoria trina, conforme Reale (1992), Lask e Radbruch, na Alemanha; Vanni e Del Vecchio, na Itália; Roubier, na França; Pound, Stone, Cairns e Friedmann, nos países anglo-americanos; Legaz y Lacambra, Maýnez, Cóssio e Siches, na cultura Ibérica. Tais autores se constituem como tridimensionalistas abstratos, Revista de Direito Brasileira | Florianópolis, SC | v. 27 | n. 10 | p.412-440 | Set./Dez. 2020
} 
panorâmica. Antes, eleger-se-á, como mais expressiva, a reflexão tridimensional concreta de Reale, nomenclatura que se deve ao fato de o autor compreender que o fenômeno jurídico resulta não da relação meramente abstrata entre fato, norma e valor, mas da conjugação dialética, de cariz complementar, de tais momentos do direito.

A teoria tridimensional do direito, de Reale, apresenta, como elemento de ineditismo, a correlação dialética e complementar entre os três planos do Direito, de modo a uni-los numa unidade integrante. Não por outra razão, a doutrina eclética do autor será denominada de teoria integral do direito (MEDINA, 1995). Trata-se de uma correlação dialética entre fato, valor e norma, de natureza ontognoseológica (REALE, 1992). Conjugam-se, sob esse pretexto, gnoseologia e ontologia para que a realidade trina do fenômeno jurídico possa se manifestar.

$\mathrm{O}$ aspecto gnosiológico da construção dialética realeana reside no fato de os objetos que se dão a conhecer estarem sempre referidos a um sujeito cognoscente, que, tendo o seu ser como o próprio dever-ser, isto é, afigurando-se como valor-fonte de si mesmo e de outros valores, conhece os objetos enquanto esses mesmos valem. A relação sujeito-objeto permanece em constante tensão dialético-complementar, de modo que não se resolveria, em tese, em favor de primados epistemológicos, seja para a categoria sujeito, seja para a categoria objeto. Não se trata, portanto, da dialética sujeito-objeto, do tipo hegeliano-marxista (REALE, 1992).

De outro lado, todo conhecimento do direito, por mais que se dê na díade epistemológica sujeito-objeto, recorre sempre a uma ontologia. Se, para Reale (1992), ser e dever-ser estão postos em identidade, então, a ontologia mesma deverá se revelar como axiologia. A correlação ontognoseológica, dessa vista, permitirá reconciliar o conhecimento do direito com o que lhe escapa em termos de valores, desde uma perspectiva dialético-complementar, de modo a ligar os pontos de distância entre gnoseologia e ontologia e, assim, realizar e concretar a vida trina do fenômeno jurídico. O problema dos tridimensionalismos abstratos do direito residiu, portanto, no fato de tais não relacionarem os elementos mesmos do fenômeno jurídico (fato, valor e norma), desde uma perspectiva integradora e fundante, que se potencializasse pela administração intelectiva de uma dialética de complementaridade (REALE, 1992).

O juspositivismo realeano rende sólidas contribuições à filosofia jurídica brasileira e torna Reale um expoente, sobretudo no pensamento latino-americano, no que concerne à teorização tridimensional a respeito do direito, embora Reale não faça reivindicações expressas em suas obras, desde um ponto de vista pós-colonial ${ }^{7}$ ou ainda decolonial ${ }^{8}$. Os matizes do juspositivismo eclético, presentes no pensamento do autor, são incontestáveis. A axiologia, proposta por Reale, denuncia o sentimento bastante recente de que o positivismo jurídico pós século XVIII ainda não está preparado para romper com a tradição jusracionalista do direito natural. Nesse sentido, o tridimensionalismo dinâmico, proposto pelo autor, parece ser uma tentativa de síntese, ao modo kantiano, entre o idealismo jusnaturalista e o empirismo juspositivista, que cumpre o escopo de se resolver em favor do idealismo. A pretendida síntese realeana tende ao jusracionalismo, já que Reale postula, no que concerne aos valores, algo de muito similar ao kantiano juízo sintético a priori, o que constitui ponto nevrálgico em sua teoria, postas as bases historicistas afirmadas pelo autor'.

em razão de preservarem os momentos do direito (fato, valor e norma) de uma relação material e concreta. Cumpre salientar que Reale (1961) compreende o positivismo kelseniano como um tipo de tridimensionalidade, de cariz metodológico-negativo, pelo fato de Kelsen determinar previamente três objetos de pesquisa, a saber: o jurídico, o sociológico e o filosófico. Estes dois últimos objetos estariam, assim, excluídos do domínio epistemológico da Ciência Jurídica, embora, a presença irredutível de três dimensões resultasse admitida, ainda que abstratamente, no tocante ao fenômeno jurídico.

${ }^{7}$ Para uma reflexão a respeito do pós-colonialismo, v. Boaventura de Sousa Santos (2008).

${ }^{8}$ Sobre a proposta decolonial e sua diferença epistêmica com relação ao pós-colonial, v. Mignolo (2011).

9“[...] ao admitirmos a historicidade do valor estaríamos a dizê-lo como circunstância, como tempo, como mutabilidade, o que negaria seu caráter permanente. A seu turno, ao cristalizarmos a noção de valor como Revista de Direito Brasileira | Florianópolis, SC | v. 27 | n. 10 | p.412-440 | Set./Dez. 2020 
O juspositivismo de Reale, em sua parte ontológica, pretende fundar o direito numa realidade dada como aprioridade: o valor. As invariantes axiológicas, enquanto valores que se objetivam na vida histórica (REALE, 1991), elevados ao grau de imutáveis pela sua relevância, consignam o ser do homem nos consensos que se vão positivando nos infinitos diplomas legislativos. Embora não ausente o apelo da vida fática e nem abstraídos os processos normativos de instauração do direito positivo, está pressuposto o ente como totalidade de um ser ainda oculto em sua história. Assim, apesar de Reale dissolver o direito numa realidade trina e conectar as suas moléculas mediante a abstrata administração de um método dialético, o ser mesmo do jurídico persiste em sua resistência, velado e distante, ausente de compreensão. O ser se mostrou como dever-ser, isto é, como valor. Seja como universalidade cognoscente dum sujeito (gnoseologia) ou como realidade empírica dum objeto (ontologia), assim, foi, o ser, esquecido do movimento de sua verdade, de modo que se perpetuou o velamento do jurídico mesmo, obstaculizando-se a clareira.

\subsection{O positivismo formalista de Hans Kelsen e o ideal metafísico de pureza ${ }^{10}$}

Os juspositivismos estritos ou plenos pretendem ser uma teoria do direito do ponto de vista exclusivamente estatal. Aqui, parece não se fazer mais necessária a submissão à metafísica jusracionalista, vez que isso apenas se justificou em tempos em que o direito positivo ainda era, consoante Mascaro (2014, p. 338), “[...] uma novidade estranha precisando se legitimar por meio de fontes externas.". Pretende-se, dessa monta, um salto qualitativo de relevo e a superação da ambiguidade dos ecletismos, os quais planejavam conciliar, de todo modo, as reivindicações de Antígona, a bem do Divino, com as exigências de Creonte, a títulos humanos. A história alça à mesma cena da tragédia. Creonte triunfa ${ }^{11}$.

Hans Kelsen, escritor da Teoria pura do direito, é o mais conhecido expoente da doutrina juspositivista estrita, de modo que seus estudos ganham o valor de divisor de águas entre jusnaturalismos fortes e fracos e um expressivo juspositivismo. Do mesmo modo que o criticismo kantiano cinde a filosofia moderna em dois períodos, pré e pós-kantiano; a Teoria Pura "[...] é o mais sugestivo divisor da história contemporânea da reflexão jurídica: antes e depois de Kelsen." (COELHO, 1983, p. 46). O pensamento kelseniano expressa o pronunciamento de uma crítica, a qual se poderia avaliar como sendo uma das mais sofisticadas, no que concerne aos mistérios divinos da metafísica jurídica, embora, a questão do ser jurídico seja, ainda, pressuposta em

transcendência, como a priori e já-aí ante a experiência, deveríamos necessariamente negar o seu caráter de tempo e de história." (ROSÁRIO; GUIMARÃES; MOURA-MELO et al, 2016, online).

${ }^{10}$ Para os fins deste trabalho, enquadra-se a doutrina kelseniana no rol dos juspositivismos estritos, especialmente, como juspositivismo formalista. De acordo com Camargo (2003), pode-se distinguir os formalistas ou kelsenianos, dos não-formalistas ou não kelsenianos. Aqueles privilegiam o que está validamente posto na lei, em desprezo de quaisquer indagações crítico-valorativas; enquanto que, os últimos, reconhecem a interdisciplinaridade do fenômeno jurídico, apesar de ressalvarem seu caráter científico. Ademais, frise-se que o enquadramento de Kelsen entre os juspositivistas fora feito pelo próprio autor, ao se referir à sua doutrina formalista (BOBBIO, 1993; ABAGGNANO, 1982). No mesmo sentido, Streck (2010), para quem a doutrina de Kelsen traduz um juspositivismo normativista e Mascaro (2014), para quem traduz uma especialidade de juspositivismo estrito.

${ }^{11}$ Faz-se referência à obra Trilogia tebana, de Sófocles (496-406 a. C.), cuja terceira parte, intitulada de Antígona, parece deixar ver um clássico embate entre o direito positivo e o direito natural. Antígona, filha de Jocasta e de Édipo, seu pai e irmão, insurge-se contra Creonte, seu tio materno, em razão de um decreto por ele editado que proibia que seu irmão, Polinices, tivesse honras fúnebres prestadas em seu favor. Antígona, alega o direito divino (Thémis) contra o direito positivado (Diké), como se pode extrair do emblemático diálogo: "CREONTE - [...] tiveste a ousadia de desobedecer a essa determinação? ANTÍGONA - Sim, pois não foi decisão de Zeus; e a Justiça [Diké], a deusa que habita com as divindades subterrâneas, jamais estabeleceu tal decreto entre os humanos; tampouco acredito que tua proclamação tenha legitimidade para conferir a um mortal o poder de infringir as leis divinas [Thémis], nunca escritas, porém irrevogáveis; não existem a partir de ontem, ou de hoje; são eternas, sim! E ninguém pode dizer desde quando vigoram! Decretos como os que proclamaste, eu, que não temo o poder de homem algum, posso violar sem merecer a punição dos deuses!". (SÓFOCLES, 2008, p. 96). Nesse sentido, consultar a obra traduzida por Jean Melville, publicada pela Martin Claret, em São Paulo, no ano de 2008.

Revista de Direito Brasileira | Florianópolis, SC | v. 27 | n. 10 | p.412-440 | Set./Dez. 2020 
ignorância à diferença ontológica ser-ente. Se, por um lado, a pretensão epistemológicometodológica de pureza kelseniana forja evidências de objetividade e de segurança no direito, adjudicando-lhe cientificidade; por outro, essa pretensão revela-se, ela mesma, como um ideal metafísico e ideológico a respeito da relação sujeito-objeto.

Kelsen (2013) distingue entre Direito e Ciência do Direito. O Direito, em seu aspecto fenomênico, isto é, tal como se apresenta em sua forma bruta, no mundo do ser, mistura-se a outros fenômenos igualmente sociais, de modo a reunir-se à Filosofia, à Sociologia, à Religião, à Ética etc. Kelsen, assim, reconhece "[...] a incidência dos valores de ordem política e moral no direito, ainda que não os assumo como próprios à ciência jurídica." (CAMARGO, 2003, p. 115). No que respeita ao estudo da Ciência do Direito, deve se ter em conta um princípio epistemológicometodológico de pureza, de modo que as proposições descritivas a respeito da norma jurídica se restrinjam ao direito exclusivamente estatal, sem recursos extra-normativos a uma ordem supraestatal de caráter especial. Dessa forma, não só seria necessário romper com a tradição jusnaturalista do passado a que, conforme Bobbio (2006), estabelece-se um primado com relação ao direito positivo no período medieval ${ }^{12}$; mas, para que o positivismo jurídico pudesse elevar o direito à categoria de ciência, de uma vez por todas, fazia-se igualmente fundamental divorciar o seu domínio epistemológico de quaisquer possibilidades ecléticas de descrição do fenômeno jurídico. Isso se opera, na ciência do direito, pela administração de um princípio epistêmico de pureza.

Kelsen entendeu a pureza no direito, a partir da inicial importação teórica do método transcendental kantiano. Todavia, a partir da publicação, em 1945, de sua Teoria Pura, o mestre austríaco abandona o sentido transcendental de pureza e empresta ao significante a ideia de uma mundificação de elementos éticos e sociológicos. No nível político-ideológico do princípio da purificação, nota-se uma relação muito próxima entre ideologia e política. Para Kelsen (2013), a ideologia traduz mera deformação do objeto, em sua objetividade, normalmente potencializada por discussões de cunho político, que nada acrescentam à Ciência do Direito. Kelsen, entretanto, opta por um sentido de ideologia bastante estrito, o que torna a sua reflexão, ao mesmo tempo que escusada de se traduzir como ideológica, um tanto superficial.

Trata-se de uma opção redutora a respeito do conceito de ideologia, que padece, consoante Warat (1983, p. 43), pelo fato “[...] de esquecer sua inscrição material nas relações sociais.”. Não se trata, obviamente, do conceito de ideologia que é articulado pela Escola do positivismo lógico ${ }^{13}$, o que permitiria afirmar a teoria kelseniana como sendo uma doutrina ideológica do direito. Warat (1983), em acordo com Carcova, frisa que a noção de ideologia que Kelsen tem em vista, ao compor suas críticas, identifica-se com a ideia de erro ou mentira, ou, ainda, como o consciente intento individual de fraudar a verdade objetiva, a partir da motivação de preservar determinado estado de coisas ou de substituí-lo.

Kelsen (2013), entretanto, admite a impossibilidade de se rechaçar, de todo, as influências da ideologia sobre o fenômeno jurídico. O autor reconhece que o ideal de Ciência, aplicado ao Direito e ao Estado, à revelia das ideologias políticas, possui maior possibilidade de ser em um período de equilíbrio social. Warat (1983, p. 45) percebe, já neste ponto, que "[...] a teoria kelseniana revela-se como um programa metafísico sobre o que a ciência deveria ser [...]", de modo a se consolidar uma instância política na própria epistemologia jurídica. Nessa linha de raciocínio,

\footnotetext{
${ }^{12}$ Para Bobbio (2006), no período clássico, não se tinha o direito natural como superior ao direito positivo, e vice-versa, mas ambos estavam igualmente dotados de igual valor de verdade e se relacionavam a partir da máxima lex specialis derogat generali, de modo que o direito positivo, posto seu caráter relativo e particular com relação ao direito natural, prevalecia quando se instaurasse um conflito entre ambos. Na Idade Média, posto o fundo teológico do direito natural, enquanto norma fundada na própria vontade de Deus e presente na razão humana, constrói-se para ele uma primazia frente ao direito positivo.

${ }^{13}$ Conforme predispõe Warat (1983), a noção de ideologia tida pelo positivismo lógico se deduz da ideia de que os enunciados só adquirem sentido se corresponderem aos fatos, de modo que, qualquer outro tipo de enunciado resulta destituído de sentido e entendido como mera especulação metafísica ou ideológica.
} 
a tentativa kelseniana de delimitar o objeto da ciência do direito com relação à política se traduz, sub-repticiamente, como uma política do direito, como uma ideologia de como o direito deve ser, portanto, como uma ideia metafísica a respeito do fenômeno jurídico. Kelsen, ao tomar política como ideologia e ao reduzir o sentido destes significantes ao ideal "problemático" de justiça, incorre num equívoco que supera os quadrantes do que seria uma ingênua discussão terminológica para revelar uma semântica perversa, que prima pelo poder, mediante a presença opaca do discurso.

Kelsen (2013, p. 90) aduz que a "Justiça é um ideal irracional. Seu poder é imprescindível para a vontade e o comportamento humano, mas não o é para o conhecimento. A este só se refere o direito positivo, ou melhor, encarrega-se dele.". Dizer irracional, aqui, implica dizer insuscetível de se captar pelo logos, de onde não se pode forçar a afirmação de que a justiça seja um ideal inexistente, ou ainda, uma meta falsa e impossível. Aqui, está posta uma das grandes objeções kelsenianas ao Direito Natural, a qual deve, com fidelidade, fazer jus ao criticismo que é levado a cabo, sem resultar na negação daquela doutrina. Frise-se, Kelsen não está a negar veracidade às doutrinas jusnaturalistas. O projeto do autor consiste, ao revés, na promoção de um deslocamento de tais doutrinas para um novo lugar no discurso. Nada obstante o fato de Kelsen negar realizabilidade objetiva, a nível de ciência, aos jusnaturalismos, não lhes destituí de alguma verdade, no nível do "extra-objetivo". A Teoria Pura terá como objeto, todavia, apenas aquilo que se pode determinar como cognoscível e apreensível para a racionalidade científica. Estão delimitados, no domínio da epistemologia jurídica, os limites entre razão teórica e razão prática.

De acordo com Warat (1983, p. 60), a atitude metodológica antijusnaturalista pretende, em adesão às bases epistemológicas juspositivistas, “[...] conquistar uma leitura objetiva e desideologizada dos discursos do saber jurídico tradicional, visando a constituição dos pressupostos de uma Ciência jurídica positivada.”. Almeja-se alçar a um espaço teórico neutralizado ideologicamente, o que só seria possível a partir de uma dialética combativa das doutrinas jusnaturalistas. O conceito de "dever ser" passa por uma desideologização, de modo a ser lido formalmente como vetor lógico de apelo a um princípio de imputação.

Entretanto, a redução anti-metafísica do direito ao dever ser formal não se opera mediante o recurso à lógica proposicional das ciências naturais. Não se trata de uma vinculação causal entre as proposições descritivas, mas de um vínculo por imputação. O princípio de causalidade organiza os enunciados descritivos da seguinte maneira: se x, então y. A técnica de imputação, ao revés, aperfeiçoa-se, no entender de Kelsen (2013), em enunciados do tipo "se não x, então deve ser y". O princípio anticausalista planeja, portanto, inibir sincretismos metodológicos. A Ciência do Direito, a qual se discerne das outras ciências normativas pela ideia de sanção, possui a função exclusiva de produzir as proposições explicativas do significado atinente ao sistema de normas jurídicas, os quais se ligam pela técnica argumentativa da imputação.

A imputação, de acordo com Warat (1983), deve ser lida como uma categoria capaz de tornar manifestas as operações mentais a que se submetem os atos inseridos no sistema da natureza, de modo que lhe sejam atribuídas significações normativas, as quais se expressam a partir de um juízo condicional, do modo "se, então". Em tais proposições, o verbo "dever" (Sollen) funciona como elemento lógico-relacional, que permite que o sentido normativo dos enunciados resulte aperfeiçoado. A função metodológica do verbo em questão é, assim, não moral, de modo que expressa uma relação unicamente deôntica e funcional, desprovida de significações de ordem metajurídica. Os enunciados normativos, monologicamente significados, têm seu conteúdo determinado pela fórmula "se não p, então deve ser s", distinguindo-se entre as normas primárias, as que estabelecem a conduta abstratamente, e as normas secundárias, de estrutura semelhante à acima apontada com a fórmula "se não p, então deve ser s".

Warat (1983) frisa que, para Kelsen, no momento em que as Ciências Jurídicas têm seu núcleo comum composto por um conjunto de regras, que funcionam como crivos lógicos e bases categoriais de sistematicidade relativa; os conceitos fundamentais atinentes a essa Ciência negociam sua pretensa universalidade, de modo a deixarem de se traduzir como categorias 
reificadas e metafísicas. Tornam-se, assim, noções concretas e suscetíveis de controle empírico. Desse modo, o objeto cognoscível "direito" divorcia-se de concepções metafísicas para sujeitar-se unicamente ao espírito, despido de quaisquer significações legitimatórias, de modo que se torna apreensível pelo pensamento hipotético-dedutivo.

O princípio epistêmico de pureza, enunciado por Kelsen, possuirá, pelo menos, cinco braços metodológicos, todos eles capazes de revelar a intenção de alterar o núcleo ideológico comum presente nas reflexões jusfílosófico-dogmáticas (WARAT, 1983), a saber: a) evita-se nutrir a Ciência Jurídica de propósitos políticos e do recurso descabido às doutrinas jusnaturalistas; b) pretende-se obstar a reprodução do paradigma das ciências causais e de seu princípio de explicação e de descrição. Elege-se, portanto, a técnica retórica de imputação; c) rechaça-se os aportes interdisciplinares e as leituras dialógicas sobre o objeto cognoscível direito; d) demarca-se a Ciência Jurídica com relação às demais ciências sociais normativas, a partir de critérios singularizados, tal como o conceito de sanção, após submetido a um procedimento de desideologização; e) por último, restam desqualificados princípios classificatórios e de organização que articulem uma linguagem de dualidades ontológicas, de modo que os imorredouros álibis jusnaturalistas possam resultar destituídos, in esentia, da reflexão jusfilosófica mesma.

Desde esse prisma, Estado e Direito colidem como sendo uma mesma realidade normativa, posto que uma concepção dualista a respeito de tais, que os diferencie, possuiria apenas uma função ideológica. Como expõe Kelsen (2013, p. 170), um conhecimento do Estado que se pretenda divorciado da ideologia e de propostas metafísicas, "[...] não pode apoderar-se de sua essência de outro modo senão concebendo essa formação social como um ordenamento da conduta humana.". O equívoco reside no fato de se conceber a essência do jurídico mesmo, isto é, o seu ser, como sinônimo de um ordenamento posto, capaz de regular a conduta humana, apreensível em sua pureza, em abstração da história, da ideologia e do sujeito. De objeto duma meta-axiologia transcendental passa, o ser jurídico, a ser interpretado como pura objetividade, como ente manuseável e passível de circunscrição racional, como objeto da sensibilidade sobre o qual se lança um projeto ôntico de jusciência.

\subsection{Ronald Dworkin e a compreensão moral do direito}

Até agora, foram tematizadas as propostas de compreensão e de explicação do fenômeno jurídico do ponto de vista da jusciência. O pensamento de Reale, mesmo que presente uma fundamentação axiológica, sem prejuízo do domínio fático, traduz uma concepção ontognoseológica do Direito, que, como se viu, não se resume à descrição do ser do fenômeno jurídico como dever-ser, mas agrega-lhe um fundamento gnosiológico, que diz respeito a como o sujeito cognoscente se alinha ao objeto cognoscível-direito. O valor, assim, em Reale, não permite que se engendre um moralismo jurídico, posto não estar em jogo, ainda, com expressividade visível, o problema da racionalidade prática no tocante à compreensão do Direito. Tanto em Kelsen, quanto em Reale, o legado kantiano da Razão Pura permanece sendo revisado e revisitado no tocante ao fenômeno jurídico, em prejuízo da diferença ontológica ser-ente.

Bem distante dessa proposta juscientífica irá se situar a teoria jurídica atinente à segunda metade do século XX. Nesse locus temporal, inaugura-se uma tentativa sofisticada de se reconciliar o Direito com a Moral, a partir da sustentação de uma moralidade intrínseca que supostamente fosse inerente àquele, ou, caso considerada extrínseca, fosse ela suscetível de um cálculo objetivo e probabilístico. Nessa trilha, caminham os teóricos a que se atribui um juspositivismo ético, entre os quais se destaca Ronald Dworkin, em razão da contundência de seu liberalismo político aplicado a direitos ${ }^{14}$. A razão prática assume um protagonismo que sequer pelas doutrinas ecléticas do direito fora suficientemente experimentado.

\footnotetext{
${ }^{14}$ Citem-se, além de Dworkin, os estudos de John Rawls, Robert Alexy e Jürgen Habermas, igualmente precursores de doutrinas juspositivistas éticas (MASCARO, 2014).
}

Revista de Direito Brasileira | Florianópolis, SC | v. 27 | n. 10 | p.412-440 | Set./Dez. 2020 
Dworkin (2002) identifica os elementos fundamentais que uma teoria do direito, que se pretenda geral e completa, deverá possuir. Segundo o autor, uma Teoria Geral do Direito deve possuir uma parte conceitual (ou descritiva), que se ocupe do que o direito é, e uma parte normativa, que resolva questão de como o direito deve ser. Para o teórico norte-americano, uma teoria dessa envergadura pode ser encontrada nas reflexões de Jeremy Bentham. A parte conceitual da teoria de Bentham se convola em um juspositivismo. Já, em sua parte normativa, exprime-se como utilitarismo. Tais tendências constituem o que Dworkin rotula de teoria dominante do direito, contra o que irá engendrar as suas críticas mais ferrenhas.

Nada obstante, as críticas do jusfilósofo norte-americano não recairão imediatamente sobre a doutrina benthaniana, tomada em seu aspecto integral. Dworkin elege Hart, a quem sucede na cátedra da Universidade de Oxford e de quem fora aluno, como alvo próximo de suas sofisticadas objeções, as quais, de muitos modos, aproveitam-se ao seu alvo remoto. O positivismo jurídico de Hart se consubstancia, assim, a partir das lentes de Dworkin, na mais altiva construção teórica do gênero de que faz parte.

As objeções dworkinianas ao juspositivismo de Hart se concentram em duas questões fundamentais. A primeira diz respeito à conceituação do Direito como modelo de regras. A segunda, ao problema da discricionariedade. Dworkin (2002) desenvolve a sua primeira objeção a partir da distinção entre regras, princípios e políticas e da contestação da regra de reconhecimento, tomada como teste de pedigree. O autor não recusa as definições juspositivistas do significante "regra". A proposta do mestre norte-americano, ao revés, militará em favor do reconhecimento de outros padrões normativos (standards), que extrapolam o conteúdo semântico desse significante. Trata-se das políticas e dos princípios.

Ao passo que as políticas se traduzem como objetivos econômicos, políticos ou sociais, de cunho genérico, que instauram um estado de coisas de natureza deôntica ligado ao "coletivo" e ao "em comum"; os princípios se referem àquela dimensão da moralidade que se liga à justiça, tomada em seu aspecto individual e em seu substrato ontológico. Os princípios ainda se distinguem das regras, posto o fato de em tais, diferentemente das regras, não se verificar uma aplicabilidade excludente, ao modo "tudo ou nada", que imponha determinada decisão particular. Ao revés, constituem-se uma ratio suficiente para o caso decidendo, de modo que se admite, inclusive, o concurso e a complementaridade entre princípios distintos, em se tratando de um mesmo caso.

A instrução argumentativa dessa tese se realiza a partir da exposição alinhada de alguns hard cases, nos quais Dworkin alega a total corroboração de suas proposições. A priori, o autor examina o caso Riggs versus Palmer. Em 1989, um tribunal de Nova Iorque se deparou com a questão de se um herdeiro, nomeado por disposição testamentária de seu avô, após tê-lo assassinado, poderia obter ou não esse direito sucessório. Apesar da inexistência de regra proibindo o assassino de suceder, o tribunal reconheceu a força impositiva do princípio de que nenhum criminoso pode se beneficiar por seus crimes. De acordo com um raciocínio deduzido a partir das regras existentes, estaria o assassino autorizado a receber a herança, posta a omissão explícita do sistema jurídico a esse respeito. Nada obstante, os juízes entenderam ser moralmente inaceitável que isso se efetivasse. A literalidade da lei restou equivocada.

Dworkin (2002) examina uma segunda situação emblemática. Trata-se do caso Henningsen versus Bloomfield Motors, Inc., em que um tribunal de New Jersey se depara com a questão de se seria ou não possível a um fabricante de automóveis limitar sua responsabilidade, em se tratando de automóveis defeituosos, pela via contratual. Igualmente, embora inexistentes disposições literais, que tivessem o condão de impedir tal escusa de responsabilidade por parte do fabricante, o tribunal pugnou pela sua responsabilidade em indenizar quando se reconhecessem defeitos no produto, raciocínio que não deverá conduzir à destituição da normatividade do princípio geral da liberdade de contratar, fixada a obrigação especial que tem o fabricante quanto à fabricação, promoção e venda de seus carros. Mais uma vez, o que se verifica é uma decisão com base em um padrão normativo de natureza "extrajurídica". 
Dworkin (2002) passa ao exame da tese hartinana a respeito da validação das regras, a que se refere como "teste de origem" ou "teste de pedigree". Conforme o mestre norte-americano, esse teste se deduz de uma suposta regra de reconhecimento, que permitiria, mediante uma análise formal da regra respectiva, conferir-lhe validade. Entretanto, e essa é uma das falhas apontadas por Dworkin a respeito do positivismo, a regra de reconhecimento apenas serve ao intento de identificação de regras, de modo que o exame de validade, que se sustenta no tocante à tais padrões normativos, não se aproveita aos princípios. Dessa forma, o teste de pedigree, enquanto critério de aferição da validade das normas-regra, não se constitui um meio investigativo seguro, em se tratando de outros padrões, sobretudo quando aplicado aos hard cases. A respeito destes, afirma a teoria positivista que, a depender do grau da dificuldade de formação do juízo racional juridicamente pautado por regras, presentam-se lacunas, as quais instam o julgador a decidir com base em suas convicções. Tem lugar, desde esse ponto, a segunda objeção dworkiniana ao positivismo de Hart. Fala-se, assim, no exercício de um suposto poder discricionário, com que o autor norte-americano não conviverá harmoniosamente.

Dworkin (2002) entende que o julgador sempre deve pautar seu juízo por padrões normativos, sejam eles jurídicos ou morais. Ausentes as possibilidades juridicamente previstas de argumentar em torno de um decisum, o juízo de decisão do julgador resta ainda vinculado aos princípios. Fala-se pelo menos em três sentidos de discricionariedade, de acordo com a doutrina dworkiniana, sendo que dois deles se denominam de "sentidos fracos" e o terceiro, de "sentido forte". A escolha por parte do juiz entre critérios interpretativos se traduz como discricionária. A decisão tomada por uma autoridade superior também se configura como discricionária. Mas a acepção forte do termo em questão só se deixa ver quando é estabelecida a possibilidade de o juiz decidir à revelia de quaisquer padrões normativos existentes, mediante o uso arbitrário do poder. Nesse ponto, o positivismo se depara com uma contraditio in adjecto, que pronuncia a sua sentença de debilidade lógica.

Nada obstante a abertura moral que promove, a justeoria de Dworkin a respeito do ser jurídico ainda se move numa compreensão inautêntica desse ser, como parte de sua história, como história conhecida dessa presença. O jurídico ainda é encarado como resultado da compreensão de uma realidade posta, ainda que sob um projeto moral. Além disso, a sustentação de um sujeito cognoscente de capacidades sobre-humanas, como é o juiz Hércules, parece constituir um primado espistemológico perigoso, sob o qual arriscadamente se funda toda uma teoria. Nem o ser é compreendido em sua liberdade, nem o ente humano deixa que esse ser possa, de si mesmo, (des)velar-se. O império do sujeito racional se afigura plenamente estabelecido, em torno de uma moralidade esvaziada de sua ontologia, sob nítidos pretextos universalistas. São reinventadas categorias kantianas da razão pura para uso em dilemas da racionalidade prática. Ainda se toma o ente, pelo ser, ainda se articula uma linguagem de dualidades.

\section{A EK-SISTENTIA, O LUGAR E A FINALIDADE}

O pensamento pereceu. A invenção da verdade, a criação da filosofia e a gênese do método racional, mudaram a vida de estética a estática. A experiência contemplativa dos físico-naturalistas oscilou para uma compreensão parcial da physis. E surgiu a ideia, a alma, as essências, a cisão natural-artificial. A cultura e o espírito opuseram-se ao corpo vivo. $\mathrm{O}$ verbo tornou-se carne. $\mathrm{O}$ mito e o mistério foram furtados de sua retórica. A ideologia, a metafísica e o discurso tornaram-se os novos titãs. E forjou, Prometeu, no fogo dos deuses, a moderna ciência. A Filosofia dá à luz ao instrumental, à técnica. Mas, na era da técnica. poderá o pensamento poder? Terá a verdade, enquanto veritas, condenado o ser ao seu esquecimento fatal e irremediável? Muito pelo contrário, entenderá Heidegger.

A gravidade da questão do ser e a repetição da pergunta pelo seu sentido orquestram a denúncia da objetividade dos entes. O pensamento pode avessar-se, a linguagem pode dobrar. Está 
posta a tarefa do pensamento na era da técnica. É quando a questão pode questionar-se, quando pensar o pensamento tornou-se decisivo, numa investigação que se inicia no mostrar-se dos fenômenos para perpetuar-se pelas nuances da clareira. As artes, a ciência, a filosofia e o direito se veem diante do fim de um modo de pensar que se exauriu na técnica. Mas o lugar que se inaugura deixa ampliar a compreensão desse modo de pensar que se objetivou. O pensamento pensado pela tradição passa a ser tido como uma possibilidade da história do ser que se assumiu. Entretanto, não estarão esgotadas as possibilidades desse ser, tampouco está-se longe de, do pensamento, ter-se uma visita. Nesse horizonte, o recurso às jusfilosofias de Aloysio Ferraz Pereira e Jeannette Antonios Maman se apresenta como extremamente decisivo para uma compreensão ontológicofundamental do fenômeno jurídico, à luz da situação ek-sistencial do povo brasileiro.

\subsection{Da Ek-sistentia}

A repetição da pergunta pelo sentido do ser introduzida no âmbito do jurídico, observará as possibilidades desse ser se (des)velar. De acordo com Heidegger (2005, p. 80)

Somente na medida em que o homem, ex-sistindo na verdade do ser, a este pertence, pode vir do próprio ser a adjudicação daquelas ordens que se devem

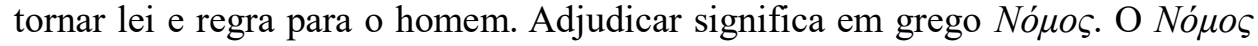
não é apenas lei, mas, mais originariamente, a adjudicação oculta na destinação do ser. Só esta é capaz de dispor o homem no seio do ser. Só tal disposição é capaz de sustentar e vincular. De outra maneira toda a lei permanece apenas no artifício da razão humana. Mais importante que qualquer fixação de regras é o homem encontrar o caminho para morar na verdade do ser (grifo nosso).

Dessa maneira, a palavra direito, mediada pela justiça, torna-se hábil a explicitar a destinação ek-sistencial de um povo, implícita no ser. Ek-sistentia, aqui, deve ser lida de modo distinto do entendido pela tradição. Nesse sentido, Heidegger (1970) refuta tanto o termo "esentia" quanto "existentia". Conforme o filósofo, o emprego de tais termos remete à tradição metafísica, fazendo eco ao esquecimento do ser enquanto tal. Por isso, Heidegger moverá duras refutações à filosofia de Sartre, principalmente, o qual, embora seja reconhecido como uma espécie de continuador das reflexões daquele, padece pela construção de suas reflexões sob a égide da noção tradicional de "existentia". Heidegger, assim, propõe pensar, para além dos humanismos, o ser do homem existente como ek-sistentia, já que, conforme o autor, essa perfomance de linguagem preserva o caráter ek-stático do ser do homem.

La metafisica se cierra al sencillo hecho esencial de que el hombre solo se presenta en su esencia en la medida en que es interpelado por el ser. Solo por esa llamada «ha» encontrado el hombre donde habita su esencia. Solo por ese habitar «tiene» el «lenguaje» a modo de morada que preserva el caracter extatico de su esencia. A estar en el claro del ser es a lo que yo llamo la ex-sistencia del hombre (HEIDEGGER, 1970, p. 27).

Heidegger (1970) compreende que somente o homem habita esse modo de ser, somente a ele esse modo de ser é próprio, já que "La esencia extatica del hombre reside en la ex-sistencia, que sigue siendo distinta de la existentia metafisicamente pensada." (p. 30). Esse modo de ser do homem, reside num estar-fora, num modo ser desinteriorizado, sem essência ao modo da tradição. O ser-aí ek-siste por lançar-se ao mundo e ao outro, conforme o seu ser. Por isso, será esse o termo empregado por esta pesquisa, uma vez que o mesmo deixa ver de modo mais subterrâneo o modo de ser do ser-aí.

Ademais, da compreensão do jurídico enquanto modo de adjudicação oculta na destinação do ser, que insta disposições capazes de sustentar e vincular o existente a determinadas ordens, 
conforme exposto linhas acima, irá emergir a filosofia do direito dos juspensadores Pereira e Maman, como precursores brasileiros da escola da Filosofia existencial do direito, proposta que pensamos poder ser aliada aos estudos de Streck em sede de hermenêutica jurídica e jurisdição constitucional. "Ajustando-nos ao ser, em seu desdobrar-se seremos conduzidos, ao mesmo tempo, à manifestação da verdade dos entes e ao encontro do nosso próprio sentido, nosso próprio destino." (PEREIRA, 2003, p. 12). Trata-se de um regresso a um tipo de compreensão do jurídico que fora encoberto pela tradição, um modo de ir ao direito mesmo sem confundi-lo com o ente, isto é, com as positivações.

Pereira (1980b) aduz que, se a história da jusfilosofia traduz a dialética entre jusnaturalismo e juspositivismo, conforme René Marcic, então, com fundamento em Heidegger, será possível sustentar que "[...] os grandes juristas ou pensadores do direito pensaram a mesma coisa." (p. 159). Ora, tanto o jurídico enquanto ideia, discurso racional, incorreu na parcialidade de pensar como ente aquilo que é ser, como fez o jusnaturalismo; quanto o positivismo jurídico buscou na sensibilidade, no texto normativo, a fundação da racionalidade jurídica. A tradição legada por esses modos de compreender o direito conduziu, assim, ao esquecimento do ser jurídico.

A repetição da pergunta pelo ser jurídico se poderá abrir ao homem na integridade de sua existência, isto é, “[...] ao homem, enquanto ser-aí, em sua situação existencial.” (PEREIRA, 1980b, p. 160). Mas não se trata de uma pergunta racional e metodicamente determinada. Nesse mister, método, técnicas e diplomas só têm a atrapalhar. Tais recursos, sejam eles técnicos, científicos ou metafísicos, "[...] têm a natureza das funções e preocupações do mundo disponível e inautêntico, onde o direito é mero instrumento e a visão da justiça foi obliterada." (PEREIRA, 1980b, p. 160). A justiça, ao revés de apartada do ser jurídico, então, deverá, com ele, reconciliarse, uma vez que homem autêntico e inautêntico não poderão se sobrepor.

A experiência originária do direito, fundada na filosofia da existência, antecipa-se pela estrutura do ser-para-a-morte. $\mathrm{O}$ existente, enquanto ente lançado em sua facticidade, sobrepujado pela sua finitude, poderá determinar o seu projeto compreensivo em torno duma vida autêntica. Mas, a consideração desse projeto, no todo da existência, não poderá desprezar a situação social e política do existente que pode e já compreende o ser. Antes, no mundo da preocupação, deve-se ressaltar a relação que o ente existente ocupa no sistema de produção em que fatalmente se encontra. Assim, de acordo com Pereira (1980b, p. 160) "Não há separação entre situação limite, onde o cuidado define minha essência, onde o meu ser se comunica com o ser em geral, $e$ a minha situação no regime de produção em que trabalho ou exploro.”. A experiência privilegiada da angústia, mediada pela finitude, ou até a mera constatação do existente de seu limite mortal, deixa vir a perspectiva da ontologia fundamental, em que a função econômica e a posição de classe que o existente ocupa tornam-se decisivas.

Assim, a situação ôntico-ontológica é uma determinação de ser do homem existente, dada no horizonte de sua estrutura originária, mercê da compreensão ou sentimento dessa situação. Da mesma forma, a situação sócio-política do existente, que determina ao mesmo tempo o seu ser, de modo igualmente essencial e existencial, deriva da relação de produção em que se encontra e se translucida também através da hermenêutica, ou seja, por meio da compreensão ou do sentimento de classe. (PEREIRA, 1980b, p. 160).

A compreensão existencial do direito, desse modo, não poderá se dar à revelia da consciência de classe, posto que estar no mundo é haver-se com um mundo de desigualdade econômica e de espoliação social, isto é, estar no mundo é estar diretamente presente na história. No mundo de inautenticidade que se tem experimentado, o direito é tido como "[...] uma ordem prática de soluções, que se organiza à luz da prudência e procura a segurança e a imobilidade." (PEREIRA, 1980b, p. 161). Desse prisma, razão prática e razão teórica concorrem para garantir a imutabilidade e a segurança objeto do desejo humano. A técnica se tornou a essência da metafísica 
como vontade, de modo que a metafísica, alma da história europeia, acaba-se e se esvazia em niilismo, nulificando-se.

Para o pensamento, o que resta? Conforme Pereira (1980b), o pensamento jurídico deverá garantir a rejeição do jugo da dominação e a ocupação do centro, a emancipação da dependência cultural que generaliza a existência e a muda em essência. A rejeição da racionalidade burguesa e a assunção de uma consciência de classes. Desse fito se encarregará o direito, orientado a "[...] descobrir no movimento operário essa compreensão de classe que permite o desvelamento da verdade jurídica." (PEREIRA, 1980b, p. 164). A verdade jurídica se subsume à realidade de espoliação de um povo e, nesse contexto, deverá ser buscada.

Se, como diz HEIDEGGER, o homem é o pastor do ser, assim também o filósofo do direito será o pastor do ser-jurídico no grupo social, à escuta das necessidades do seu povo, para que todos os que trabalham possam decidir, sem mentira e sem medo, da própria situação e da sorte comum (PEREIRA, 1980b, p. 164).

Torna-se presente a definição de justiça, ou do jurídico, como um dos modos de ser do ente existente junto com os outros no mundo, isto é, como um modo de coexistir (PEREIRA, 1980a). O direito passa a se haver com uma fatal e originária experiência com o ser enquanto ser, uma vez que

[...] todas as filosofias anteriores a Heidegger, nelas compreendidas também as teorias do direito natural, dependentes que são da mesma ontologia tradicional, têm em comum as características do pensamento pré-heideggeriano, que derivam precisamente dessa ontologia, por ele denominada também de metafísica. Essa [...] é a própria essência da técnica, com a qual se confunde. Uma das tarefas a serem realizadas pelo pensamento atual consistirá, então, na destruição da história da ontologia, a fim de permitir que seja de novo posta a questão do ser (PEREIRA, 1980a, p. 166).

Dessa maneira, mesmo as distinções mais sofisticadas entre jusnaturalismos e juspotivismos tornam-se frágeis, uma vez que ambas as doutrinas recaem sob o mesmo destino da civilização ocidental. O ser jurídico se compreende como modo de ser do ser-aí, não estando reduzido a outro de seus modos de ser, isto é o conhecimento. Deve-se dar um passo atrás à epistemologia e à gnoseologia, para ir ao encontro do ontológico e do ôntico, para tornar às coisas mesmas. O jurídico se expressa, assim, como um existencial do ser-aí, de caráter concreto e universal, tendo como ponto de partida a hermenêutica, enquanto "[...] tomada de uma situação (Befindlichkeit), na qual se move existentivamente o homem, enquanto ser-aí." (PEREIRA, 1980a, p. 170).

O jurídico transparece no interior de uma situação afetiva (Befindlichkeit), de que sucede a sua compreensão/interpretação (Verstehen), enquanto projeção construtiva, de modo que o seraí, como poder-ser, torna-se a sua possibilidade (PEREIRA, 1980a). A procura pelo jurídico mesmo, assim, deverá ser engatada pela interrogação do ser-aí, posto ser ele o ente que já e sempre compreende o ser. A busca pelo jurídico, portanto, constitui-se como uma busca "[...] na essência do social, na existência e no ser da sociedade, pois ser-aí é ser mundano e social, sem deixar inteiramente de ser-si-mesmo" (PEREIRA, 1980a, p. 171). Mas, se mesmo o ser-aí pode assumir possibilidades mundanas e cotidianas, ao mesmo tempo que pode assumir o seu poder-ser; então o jurídico, como um dos seus modos de ser, segue a dupla modalidade dessa existência: a (in)autenticidade.

De início e na grande maioria dos casos, o ser-aí não é ele mesmo, no sentido da ipseidade autêntica, mas ele é os outros no modo do se (o Man alemão, o on francês). Ele é o que toda gente é, ele se porta como todos se portam. Faz o que 
se faz, diz o que se diz. A ipseidade do ser-aí cotidiano, sendo embora trivial, média, dispersa no se, é um fenômeno primordial, um existencial, incluído na constituição positiva do ser-aí. Aqui, o ser-aí, a rigor, não é: ele é o se. De tal forma que, para revelar a si mesmo o seu ser autêntico, cumpre ao ser-aí eliminar as dissimulações e ocultações, e evitar, com perseverança e esforço por vezes heróico [sic], distrações, desvios, ilusões. Tudo e todos, a começar por ele mesmo, se desdobram à tirania do se, que lhes dita o seu modo de ser e lhes prescreve as competentes sanções. E o se não é ninguém de determinado, nem a soma de todos. É toda a gente, é proteiforme. No seu torvelinho, preso sempre no medo, perde-se o ser-aí na tagarelice, na curiosidade e no equívoco. Em sua situação afetiva, sente e encontra a queda, este modo fundamental do ser da cotidianidade (PEREIRA, 1980a, p. 173-4).

Assim, a modalidade inautêntica do ser jurídico, é também compenetrada pela inautenticidade do ser-aí, isolado, solipsista e preso em si mesmo, em sua interioridade. Desse prisma, a ele não se pode $e k$-sistir, estar fora, compreender os fenômenos e haver-se com a presença do que há. "Vista a partir do mundo, a modalidade inautêntica do jurídico é manifestada pelo se. Apresenta-se freqüentemente [sic], como um ente intramundano entre os demais." (PEREIRA, 1980a, p. 174). Esse modo inautêntico do jurídico comumente se assume pela opinião pública, pela doxa, pelo senso comum teórico dos juristas (WARAT, 1995).

Pereira (1980a, 1980b, 2003) diagnostica uma situação ek-sistencial peculiar, a partir do que a compreensão do jurídico, na verdade do ser, torna-se decisiva. No mundo-aí, determinado por um universo singular, tal como é com os países de capitalismo periférico, dentre eles o Brasil, sente-se de perto a compreensibilidade do ser. A finitude é constantemente repetida, sobretudo no que concerne aos espoliados e desprivilegiados, para quem se tem tornado profissão a ascensão de velas, para quem a morte, mesmo sem querer, torna-se precoce ${ }^{15}$. Nesse antro mundano, isto é, nesse mundo de coisas (prágmata), o próprio ser-aí se vê como objeto. Torna-se natural a experiência inautêntica do direito.

Assim, "a preocupação move a existência inautêntica a criar o seu mundo disponível, recortado numa 'natureza' até então ausente, inútil, subsistente." (PEREIRA, 1980a, p. 175). O direito aparece como solicitude, assistência, como deficiência própria do ser-em-comum (Miteinandersein) cotidiano. Trata-se de um modo deficiente de cuidado. Mas, Pereira (1980b, p. 180) advoga a possibilidade '[...] de uma solicitude dos poderes políticos e econômicos que não procurem tanto substituir-se ao súdito, mas tão-somente precedê-lo (vorrausspringt) nos poderes de sua existência, não para desapossá-lo de seus cuidados [...]", mas para promover a restituição da autenticidade desses corpos. Esse é o verdadeiro cuidado, em sua dimensão ontológica. É quando a solicitude da autoridade jurídica e política pode instar "[...] o cidadão, enquanto ser-aí, a se revelar, transparente, a si mesmo, e tornar-se livre para o seu cuidado." (PEREIRA, 1980a, p. 180). Disso irá se encarregar a fenomenologia existencial do direito, como caminho metódico para o jurídico mesmo.

Os estudos de Jeannette Antonios Maman (1999, 2003, 2004, 2005, 2007, 2008) são uma continuação daqueles desenvolvidos por Aloysio Ferraz Pereira, de quem a autora foi orientanda em sede de doutoramento. Do mesmo modo que Pereira, Maman indaga da possibilidade de se situar o direito sob os horizontes de uma ontologia fundamental, tendo por base o método (caminho) fenomenológico, de cariz heideggeriano. Para a autora, a fenomenologia existencial do direito será, portanto, a "[...] linha de pesquisa que investiga, na área do direito e do Estado, as estruturas existenciais do fenômeno jurídico [...]." (MAMAN, 2004, p. 478). Torna-se imperioso contestar as correntes tradicionais da justeoria ocidental, sobre o direito e a justiça. A Justiça, como ser mesmo do jurídico, passa a ser encarada como experiência que se dá na vida fática, como vivência. Se Pereira pensou profundamente a manifestação do ser jurídico como projeto inautêntico

${ }^{15}$ Faz-se alusão à composição de Zé Kéti, Acender as velas.

Revista de Direito Brasileira | Florianópolis, SC | v. 27 | n. 10 | p.412-440 | Set./Dez. 2020 
de vida, como modo deficiente do cuidado, então, Maman refletirá, de modo mais profícuo, a respeito do método (caminho) em que se cumpre a pesquisa pelo justo autêntico. Assim, os projetos compreensivos dos autores tornam-se plenamente conciliáveis, de modo que se inaugura, para o juspensamento, uma nova tarefa, em que se torna possível anunciar outra pré-compreensão a respeito da presença do jurídico, isto é, das possibilidades autênticas desse ser se (des)velar, alinhadas aos debates contemporâneos acerca da hermenêutica jurídica e da jurisdição constitucional.

Enquanto que a fenomenologia de Husserl e de seus continuadores, Hartmann e MerleauPonty, dão azo a ciências de essências, o método fenomenológico, tal como proposto por Heidegger, excede o que seria uma rasa metodologia para se constituir como uma atitude hermenêutica, que leva à compreensão do ser como ser, em seu mostrar-se como fenômeno. $\mathrm{O}$ sentido fenomenológico de fenômeno será, assim, “[...] o aparecer puro e simples do ser em si, distinguindo-se da simples aparência, que indica o ser ou aponta para o ser, que, entretanto, ainda não se mostra, ou se esconde." (MAMAN, 2004, p. 479-480). Retoma-se a origem grega do termo fenômeno, enquanto mostrar-se, revelar-se, como um modo de encontro privilegiado com aquilo que é. "Eis aí a virada lingüística [sic] a que nos propomos. Não se pode mais pensar o direito sem vivenciar a experiência dos fenômenos com os quais nos confrontamos." (MAMAN, 2003b, p. 507). Resistir a essa virada implica alojar mais profundamente no pensamento um princípio de disjunção, que reitera a separação sujeito-objeto.

A ontologia fundamental possuirá a incumbência de esclarecer a questão do ser, enquanto questão mais geral e mais concreta, posto que ela decide do ser do ente que a põe. "A generalidade da pesquisa ontológica dá-lhe um sentido mais amplo do que as investigações ônticas das ciências positivas, pois propõe indagar da condição do ser e não do significado do ente." (MAMAN, 1999, p. 326). Trata-se de um regresso às origens gregas, de onde se tornou possível ver que o fenômeno jurídico pode existir na esfera autêntica, a partir de sua situação nos horizontes da ontologia fundamental. Assim, "nada impede a realização do 'torna-te a ti mesmo' (torna-te aquilo que tu és) no Direito.” (MAMAN, 1999, p. 326). A ordem jurídica passa a figurar como a expressão da situação ek-sistencial dos povos. Do mesmo modo que em Pereira, para Maman (1999, p. 327)

É na carência, situação limite, que se revela (se desoculta) o autêntico Direito, aquele que supre a falta de bens materiais, corpóreos e incorpóreos, e promove a igualdade pelo atendimento das necessidades vitais do ser-aí outro, constitutivamente igual ao mesmo. É no atender às necessidades existenciais do outro, que sofre privações nas coisas e na sua pessoa, que se revela o jurídico autêntico.

A consciência que deve ter o ser-aí de sua nulidade torna-se decisiva. O existente deve se haver com sua culpabilidade fundamental. E isso não se irá desvincular de certa prudência no agir ético. Torna-se a Aristóteles para reintroduzir uma razão prática, para redimensionar a jurisprudência. O justo emerge como o telos do Direito. Dessa monta, não se excluirá do ser jurídico certa “[...] 'ressonância da subjetividade' capaz de compreender, diante do rígido Direito Positivo, quais os meios hábeis para assegurar ao outro a realização de suas possibilidades." (MAMAN, 1999, p. 327). Daí, aparecerá a Justiça como modo de ser do cuidado, fundada na culpabilidade do ser-aí, em seu existencial ser-com-o-outro. "Como virtude, a Justiça é 'disposição permanente do querer o bem' bem que não-coincide com o homem, mas tem que ser realizado em si próprio, por esforço e energia em buscá-lo, pelo trabalho e pela arte." (MAMAN, 1999, p. 328). Assim, o bem irá pressupor uma relação ao outro e o movimento de busca pelo justo traduzirá uma espécie de tekhné, um fazer-se orientado ao outro, isto é, uma arte.

Mas a Justiça não assume, como critério de administração do bem, o mérito, como o foi em Aristóteles. A analítica existencial do ser-aí permite compreender que o homem não possui nenhum mérito, já que tais são iguais em sua nulidade (MAMAN, 1999). E, para que a co- 
existência se possa realizar no cuidado ontológico, faz-se mister deixar que cada um seja como é, desde que supridas as suas necessidades vitais, alimentícias, de abrigamento, saúde, educação, isto é, desde que se promova a igualdade jurídica, política, social e econômica. "É, pois, a ontologia que fundamenta a igualdade política e jurídica na existência autêntica, pelo reconhecimento da recíproca alteridade dos coexistentes." (MAMAN, 1999, p. 329). A justiça, conforme a eksistencia, passa a ser tida como modo de ser do ser-aí, tomado em seu existencial ser-com-o-outrono-mundo.

A justiça é, assim, a obra de arte que se mostra. "Não encontramos se não saímos à procura. Mas, se nos pomos a procurar é porque já encontramos." (MAMAN, 2008, p. 653). O homem se torna a sua própria possibilidade. Entretanto, ele não pode produzir-se a si mesmo, como artefato, mas deve ao revés, resistir às destinações que obstruem o seu poder-ser, como ser-livre, em pouso pleno na verdade do ser. A liberdade é a essência da verdade. A insistência em reconhecer o Direito como técnica faz-se necessária ao fito de superar a dominação que fora feita com o instrumentalismo, tendo-se em conta, com Palmier (1969), que técnica não é a mesma coisa que essência da técnica e que questionar a técnica é o caminho para a investigação nessa era.

Maman (1999) elenca, como pressupostos para uma investigação fenomenológica do Direito: a) a ordem jurídica; b) os povos; c) a expressão; e d) a situação existencial. A autora atenta para a necessidade de não se tomar ordem jurídica por ordenamento, por esse referir-se apenas ao sistema normativo, por leis, já que essas poderiam ser relacionadas às instâncias arbitrárias de poder e decisão, ou por direito, que comumente é visto como mero conjunto de normas. Trata-se de um modo de busca que preserva o se, o impessoal, como modo de ser do homem existente, junto à busca pelo ser. Há um compromisso extraordinário com a cotidianidade, no que a saída para assegurar um terreno comum entre o inautêntico e o autêntico, em que se pode encontrar o justo, é a arte.

Podemos conceituar arte [...] como a atitude integral do homem existente ao deixar constituir-se um objeto, numa estrutura qualquer de ação, contemplação e conhecimento. O justo, a solução justa, é a obra de arte do jurista, como já o era no homem justo (MAMAN, 1999, p. 330).

A arte constituirá o meio de acesso a esse modo de ser, que é a Justiça, (des)velando a verdadeira essência dos entes e do homem em seu ser, à revelia da utilidade e de sua compreensão ôntico-científica. Isso contraria, por exemplo, Karl Jaspers, para quem não há cura para o direito, sendo ele todo inautêntico, obra do se, estando a Justiça sob encargo da moral. Assim, uma ordem jurídica justa aproximará a autenticidade do inautêntico, no compromisso do extraordinário para com o cotidiano, como retorno à Justiça. Ordem assim remete à sua acepção aristotélica, estrutural. Só assim irá, a ordem jurídica, possibilitar a existência humana no mundo, em seus aspectos material e espiritual. Só assim irá ela contribuir para que a vida possa se afirmar como tal, em que o dever-ser tende à restauração e manutenção dos entes em seu ser. Diferentemente de Reale, o homem não é compreendido como o seu próprio dever-ser, isto é, como valor. Ao revés, o homem é e, sendo como é, ele pode ser, tornar e fazer, sendo o dever-ser uma proposta de encontro com o próprio ser.

A compreensão do povo como instância singular esvaziará o conceito de Estado. "Quando pensamos em um Direito para a América Latina, com hermenêutica apropriada, não introduzimos em sua representação nenhuma abstração ou símbolo, nem bandeiras, nações ou Estados." (MAMAN, 1999, p. 333). Está posto o interesse na afirmação do povo latino-americano, ao invés de uma "América Latina", isolada dos povos. Trata-se de um povo que esteve sujeito à manualidade, tornou-se disponível como meio, fora empregado para o enriquecimento do primeiro mundo. O provimento da existência material permitirá a superação do quadro internacional de subdesenvolvimento, pois, “[...] em termos planetários, a Justiça alcança uma significação de coexistência para preservação da vida e do próprio planeta." (MAMAN, 1999, p. 334). 
A ordem jurídica passa a ser tida como a expressão de um quadro existencial de um povo. Mas não ao modo das invariantes axiológicas de Reale. Maman (1999) propõe uma inversão dessa axiologia, afinal quem seria o homem para fixar seus valores supremos? A ordem jurídica só é a expressão da situação ek-sistencial de um povo, na medida em que é manifestação da ek-sistência social do ser-aí. Mas que é situação existencial? Ora, trata-se de um "[...] um conjunto de relações nas quais o ente humano existente se encontra no mundo e com os outros. Este encontrar-se, desde sempre, é o estar em situação.” (MAMAN, 1999, p. 335). Mas, o estar em situação nada mais traduzirá que um estado de derrelicção. O homem existente encontra-se lançado no mundo, isto é, abandonado a um determinismo que poderá ou não lhe ser impeditivo de agir, sendo sempre possível trabalhar para a mudança de situações. Existencial, assim, será a estrutura originária do ser-aí em sua constituição, que se encontra com o outro e no mundo, lançando-se, com os outros que ele também é, para a morte.

O fundo existencial do Direito tem como traço distintivo a sua identidade universal, de seres-para-a-morte que, derrelictos, procuram em relação sobreviver para viver. A sobrevivência passa pelo econômico, que é um modo de ser, e não um modo de ação do poder. Nisto consiste a universalidade do Direito. No particular; porém, o fato do homem viver numa sociedade e não em outra, viverem-situação, faz com que o Direito tenha múltiplas manifestações, como produto cultural, diverso e mutável (MAMAN, 1999, p. 337).

Heidegger permite visualizar que, a última das possibilidades, paradoxalmente, tornou-se uma impossibilidade: a morte. O Dasein deve se ver com sua finitude, assumindo a facticidade de seu projeto, no sentido da vida autêntica, não alienada na impessoalidade da técnica. O ser-aí deve buscar os fenômenos a partir de uma disposição, isto é, fora-de-si (ek-sistir), sem recurso à interioridade. A finitude permite encarar a vida como tal, de modo a potencializar a abertura do existente à vida autêntica. A fenomenologia é a via de acesso, já que ontologia só é possível como fenomenologia.

Conforme Maman (2007, p. 612)

No fenômeno da existência de Dasein há duas estruturas constitutivas: a existencial (que compõe o cotidiano, o estar-junto, sem a consciência do sentido deste existir, sem o exercício da capacidade de julgar, como diria Hannah Arendt) e a existenciária, onde se dá o mundo autêntico da existência-em-comum, que não se resume ao mundo da ocupação, dos ofícios técnicos, mas se traduz pelo cuidado que é manifesto na preocupação-com-o-outro.

Há, assim, a ruptura com o idealismo alemão, a partir da revisão dum projeto compreensivo pautado pela imanência do sujeito e pelo subjetivismo do mundo moderno, legado ao ocidente. O ser-aí é o ente diretamente presente no mundo, sendo, por ele, imediatamente tomado. Originariamente, o ser-aí é, portanto, ser-no-mundo, "[...] situação que faz parte de sua constituição, é elemento estrutural, no sentido de 'constituinte', o que está na origem da existência." (MAMAN, 2007, p. 613). O ser-aí, aberto ao seu ser-no-mundo, abandona o se, a inautenticidade do impessoal, assumindo, portanto, o si, isto é, podendo ser-si-mesmo, autêntico e determinado. $\mathrm{O}$ ser-no-mundo é mesmo a base antepredicativa sob a qual o ser-aí se determina como ele é (WAHL, 1962). Trata-se de um mundo compartilhado (Mitwelt) com outros entes de igual nulidade, isto é, entes que são como o modo de ser do ser-aí. O existente possui um lugar no ser do outro, ao passo que é interpelado pelo seu próprio lugar no mundo. "O Dasein é Mitdasein e não um eu isolado, onde os 'outros' significariam o 'resto' além de mim.” (MAMAN, 2007, p. 613). 


\subsection{Do Lugar}

$\mathrm{Na}$ era da técnica, em que a visão da justiça fora obliterada, a justeoria se vê numa situação-limite. Trata-se de um momento que, caso corretamente refletido, poderá originar novos caminhos para o juspensamento. O jurídico se tornou expressão da inautenticidade, apoiou-se no se, em prejuízo do ser. Jusnaturalismo e juspositivismo pensaram o mesmo. Tanto as correntes do direito natural, quanto as do direito positivo incorreram no equívoco de compreender ou pressupor o ser do jurídico como um ente disponível, captável, circunscrito aos limites da racionalidade. $\mathrm{Na}$ situação-limite, de que fala Karl Jaspers (1968), a justeoria deve se ver com o seu fim. E, as doutrinas juspositivistas, enquanto acabamento mais cotidiano do juspensamento, não escapam a essa sentença. Foram, essas últimas, alvo de infindáveis denúncias pelas teorias críticas e, antes delas, pelo próprio Marx. Marx e seus continuadores previram o fim do direito, tomando-o unicamente como expressão do se, feição inautêntica do ser-aí. O Direito, como fenômeno intrinsecamente capitalista e burguês, deveria ser gradualmente eliminado com a transição da ordem pré-revolucionária para a experiência das comunas. $\mathrm{O}$ direito positivo, alheio à existência, teria, assim, o seu fim, enquanto término, adstrito à consecução dos objetivos revolucionários do proletariado.

Mas, estarão obstadas outras possibilidades de se compreender essa situação-limite? Uma interpretação histórica da filosofia marxista do direito deverá sugerir que o direito, a que as objeções marxistas se dirigiam, era o direito posto, estatal e impenetrável. Os marxistas tomaram o direito em seu ente, de modo que perpetuaram, igualmente, a atitude de esquecimento do ser. Por essa razão, o método da práxis, como crítica que se pretende à metafísica tradicional, pensa o mesmo, mas desde outro lugar. O homo faber, que se torna oposto ao homo sapiens, desde a construção kantiana da razão prática, é um ente determinado pela luta de classes, tendo em seu entorno outros entes igualmente acabados nesse modo deficiente de dialética. A razão prática está exaurida pelo pensamento moderno (HABERMAS, 2003), de modo que se tornaram raras, porém decisivas, as possibilidades de uma experiência ontológica com o ser jurídico. O juspositivismo recebe a sua conta, tornando-se, ulteriormente, oportuno falar-se em pós-positivismos. Mas seria, propriamente, o fim desse modo de pensar? Isto, que é o positivismo, teria alçado às suas possibilidades mais viscerais, a ponto de o acabamento na técnica tornar-se o seu destino mais provável? Ou, algo ocultado na noção de fim pode ser mais corretamente colocado, de onde a compreensão adequada da situação-limite poderá ensejar um deslocamento da justeoria para um novo lugar e, consequentemente, adjudicar-lhe uma nova finalidade? É isso que supõe esta pesquisa.

O juspositivismo chega ao seu fim. Deve haver-se com as limitações de seu modo de ser tradicional, já que atravessado pela Filosofia, enquanto metafísica clássica. Nesse sentido, a resposta a que conduziria a pergunta instada por Streck (2010) seria, para esse modo de pensar, fatal. Desde esse prisma, torna-se impossível sustentar o positivismo jurídico num quadrante da história em que a virada linguística se fez eclodir da jusfilosofia. Se é verdade que a filosofia, desde sua origem ocidental, pensa o ser como ente, então, é igualmente verdade que a jusfilosofia o fez ao modo mais precário e superficial. O juspositivismo, doutrina que circunscreve o jurídico ao estritamente normativo, ao direito posto, sob as escusas de ir ao direito mesmo, tal como aparece, condena-o à inautenticidade do se, por assumir uma possibilidade do ser jurídico como totalidade. A técnica compenetrou o direito. A essência da técnica, que se viu como sendo a metafísica, passou a ser a essência do jurídico. Desde esse horizonte, é, a situação-limite, para o Direito, devastadora. Mas, como surge, no pensamento exaurido da metafísica tradicional, uma possibilidade de se indagar do mesmo, a partir do que ficara oculto, também para o Direito se tornou possível a cura para a inautenticidade. O juspositivismo pode, assim, encontrar-se com um novo lugar, fazendo eco à verdade do ser. 
A polissemia da noção de fim, assinalada por Heidegger, auxilia nesta construção compreensiva que estamos a elaborar. A questão do fim da Filosofia deve remeter necessariamente para a reflexão sobre um modo de pensar que não se enfeixe nas representações do objeto, do sujeito, e de quaisquer outras dualidades epistemológicas. A investigação a respeito da noção de fim em Heidegger poderá, assim, fornecer subsídios para se pensar as condições de possibilidade de um pensamento mesmo na era contemporânea em que predomina a técnica e os modos de acolhimento desse modo de pensar pelo ser-aí em suas determinações ek-sistenciais. Neste ponto reside a contribuição mais relevante desta pesquisa, uma vez que os horizontes abertos pela compreensão do fim do juspositivismo ainda não foram suficientemente refletidos, sequer pelos aludidos precursores da fenomenologia existencial do direito, Pereira e Maman. Trata-se de uma resposta ativa ao problema adrede formulado por Streck, que indaga das possibilidades de se sustentar o positivismo jurídico num momento historial em que a jusfilosofia se viu interpelada pela viragem ontológico-linguística.

Heidegger estará atento às possibilidades de abertura do ente humano ao apelo do ser, enquanto morada mais originária desse ente, quando afirma que "[...] nós residimos [...] sempre e em toda parte, na correspondência ao ser do ente; entretanto, só raramente somos atentos à inspiração do ser." (HEIDEGGER, 1996, p. 36). A correspondência do ser dos entes ao ser do ente humano se dá no movimento da verdade, tida como des-velamento, que independe da vontade desse mesmo ente, isto é, dando-se à revelia de sua subjetividade na clareira da diferença ontológica ser-ente. O homem, portanto, é a abertura para o ser, mas não o senhor dos caminhos de sua verdade, tampouco o senhor das possibilidades da ocorrência dessa abertura (SOUZA, 2005).

É a partir deste horizonte de especificidade que a conferência O fim da filosofia e a tarefa do pensamento, ministrada por Heidegger, construir-se-á: no entorno da questão do esquecimento da diferença ontológica ser-ente que acomete a metafísica tradicional em suas objetivações historiais, no que a história da Filosofia representa a história do esquecimento do sentido do ser, pois " $[\ldots]$ o pensamento da metafísica tradicional, ancorado na questão do fundamento, da segurança proporcionada pelo conceito, no poder do sujeito cognoscente, teria esquecido essa diferença ontológica." (SOUZA, 2005, f. 11). A preservação da diferença ontológica deve, assim, mover as reflexões heideggerianas no sentido do resgate do pensamento mesmo.

Souza (2005) adverte da necessidade de se ter em conta o sentido que Heidegger empresta à palavra fim. Uma compreensão desavisada da proposta heideggeriana conduziria ao entendimento de fim consoante um sentido niilista, como um cabal abortamento de horizontes, uma negação fatal em virtude do que o homem não escaparia à técnica. O sentido de fim deve, assim, acompanhar o vir por si mesmo daquilo que reside no velamento da clareira, como a anunciação de um mostrar ontológico do ser como ser, sem que seja incluído e captável pela razão representacional que o condena ao mundo dos entes. Assim deverá ser compreendido o excerto seguinte

O antigo significado de nossa palavra "fim" (ENDE) é o mesmo que o da palavra "lugar" (ORT): "de um fim a outro" que dizer: "de um lugar a outro". O fim da Filosofia é o lugar, é aquilo em que se reúne o todo de sua história, em sua extrema possibilidade. Fim como acabamento quer dizer esta reunião. (HEIDEGGER, 1996a, p. 96).

O todo da história do pensamento filosófico é a edificação do ente e a objetivação do ser. O império cotidiano da técnica condena a filosofia à subtração paulatina de seu telos pela ciência. Se a racionalidade representacional se expressa na linguagem lógico-científica de onde adquire sua validade, então à Filosofia nada restará caso ela preserve o seu comportamento tradicional com relação à verdade, uma vez que esse comportamento e modo de pensar estão exauridos no telos da ciência moderna, realizados no destino do pensamento ocidental europeu. Mas o que deveria ser o acabamento mais lógico do pensamento filosófico poderá significar a assunção de uma nova 
possibilidade nesse mesmo pensamento, algo que ficara oculto na clareira do ser e que responde ao envio da época presente. Mas esse envio não implica um determinismo, vez que o homem deve se tornar ouvinte e não escravo do mesmo para assim realizar a sua liberdade (HEIDEGGER, 2002a, p. 28).

Heidegger explora a relação da Filosofia com a questão do sentido do ser no transcorrer dos processos de objetivação historial. Tendo, na ontologia, o seu leitmotiv, o filósofo alemão se indaga a respeito da filosofia e de seus rumos históricos na vida do pensamento ocidental europeu, de onde compreenderá que a era da técnica traduz o seu desdobramento mais próprio. A Filosofia incorre numa fatal imparcialidade. Isso se deve ao esquecimento de que aquilo que se mostra pode se velar. Tendo preterido o velamento, a escuridão do estar-na-caverna como parte do sair-dacaverna, i. é, como parte do conceito de verdade, a tradição filosófica opera uma redução do ser como ente. Dessa impugnação resultará a diferença ontológica ser-ente. Sendo o ente tudo aquilo que é, que há e que se presenta, o ser necessariamente não poderá ser definido, uma vez que se trata do conceito mais universal e ao mesmo tempo mais vazio (HEIDEGGER, 2012), insuscetível de ser captado, em sua totalidade, pelo pensamento lógico-representativo.

O desvio da metafísica foi querer objetivar o velar-se do ser, trazer à luz, através de pressupostos lógico-racionais, o mistério próprio do ser. Sendo assim, a justa compreensão da diferença ontológica, é também a possibilidade de ampliarmos o horizonte de relação entre homem e ser. (SOUZA, 2005, f. 16).

A verdade, desde a história da metafísica tradicional, consubstancia-se num predicado atribuído a um objeto, o que se dá, inclusive, com a compreensão do ente humano, tido pela tradição como um objeto capaz de ter a essência apreendida como substância, de onde resultam os humanismos (HEIDEGGER, 2005). O ser, entificado como objeto que se dá a conhecer a um dado sujeito cognoscente, deixa de ser como é, resultando no vazio ôntico do discurso ${ }^{16}$. O ser é tomado como evidência, como manifestação de uma essência em si atinente aos objetos cognoscíveis e suscetível de representação pelo logos. Diante da compreensão hedeggeriana a respeito da história da filosofia, surge a questão do pensamento como questão primordial. Ora, se o pensamento representativo, cuja gênese é filosófica, se dissolve na era da técnica, tendo na ciência sua maior expressão, o que resta para o pensamento? Estará a Filosofia, assim, liquidada? Em última instância, que quer dizer pensar?

Para Heidegger, o pensamento mesmo é primitivo com relação às representações. Em sua mesmidade, o pensamento remete ao acontecimento, à meditação, à abertura do ser-aí à sua temporalidade desde as suas estruturas existenciais. O pensamento se dá no âmbito do silêncio, da remissão do ente que sempre compreende o ser ao nível hermenêutico da linguagem ${ }^{17}$, em que pode, o envio do pensar, anunciar múltiplas possibilidades de determinação, o que independerá de um sujeito pensante senhor de uma vontade. O mundo, assim, pode ser aberto em seus modos de ser e transpassado pelo ser dos entes que são como o modo de ser do homem, aliado ao ser dos entes que o homem não é e que se encontram como disponíveis ou à mão. "Ainda não pensamos isto se deve muito mais ao fato de que o próprio a-se-pensar se desvia do homem e até mesmo, de há muito, dele mantém-se desviado." (HEIDEGGER, 2002b, p. 114). Em suma instância, pensar e

\footnotetext{
${ }^{16} \mathrm{O}$ ôntico designa aquilo que é próprio do ente enquanto ente, enquanto que o ontológico traduz a compreensão mesma desse ente em sua entidade, no que o torna ente, isto é, da presença (ser) daquilo que se presenta (ente). Enquanto que o ôntico remete ao discurso, o ontológico remete às possibilidades de dizer, contidas no silêncio, ao âmbito da linguagem anterior às representações.

${ }^{17}$ Heidegger visualiza, na linguagem, uma dupla estrutura. A linguagem em seu aspecto hermenêutico, isto é, tomada em seu ser, e a linguagem em seu âmbito apofântico, isto é, discursivo, representável. De acordo com Carneiro (2011), o âmbito apofântico resulta de uma compreensibilidade prévia, já que, antes de dizê-las, as coisas, primeiro compreendemo-las.
} 
representar são comportamentos distintos com relação à verdade. O pensamento é mais excelente, ontológico, enquanto a representação se dá no âmbito ôntico do pensar.

[...] é preciso compreender que o pensamento, dentro da concepção usual, é fruto de um querer do sujeito e tem o papel de reduzir o ser ao objeto. Para Heidegger, essa concepção do que seja pensar, se equivoca ao acreditar que o pensamento deve gerar o novo, produzir resultados inéditos, partir de um começo absoluto. A noção que impera sobre o que seja pensar, abandona, ao tomar por evidente, o que seja agir. Heidegger entende que pensar é a mais elevada das ações, porém, ele não se refere a essa ação que precisa converter-se numa prática utilitarista. Nós só agimos quando realizamos, o realizar é a essência do próprio agir, no entanto, nós só realizamos algo a partir daquilo que já é, deixando vigorar a plenitude daquilo que é. (SOUZA, 2005, f. 31-2).

A concepção de pensamento proposta por Heidegger, assim, não desemboca numa concepção voluntarista de sujeito, conforme o que o seu acontecimento seria resultado do direcionamento metodológico de um querer tendente à origem de um discurso fundador. Antes, trata-se de uma noção mais subterrânea. Não é o ente que pode abrir-se ao ser que determina o momento de sua abertura, como se fosse capaz de percebê-lo enquanto objeto cognoscível. É ele, o ser-aí, que é interpelado existenciariamente pelo assédio do ser. Essa compreensão será decisiva para fundar as críticas de Heidegger (1996a) à Filosofia tradicional, segundo ele, responsável por uma compreensão subjetivista dos fenômenos.

Desde esse caminhar, Heidegger convida a pensar o esquecido na história da filosofia, de modo a torná-lo pensável, questionável. A Filosofia tradicional pensou o ser enquanto ente, de modo que a história do ser que se conhece é a história de seu velamento. Esse comportamento com relação ao ser é que tornou pronunciado o fim da Filosofia. Conforme Leão (2000), são três os sentidos da palavra fim que podem ser depreendidos das reflexões heideggerianas: término, plenitude e mudança. A Filosofia chegou ao seu término tendo objetivado o real, já que a ciência se fundou e se desenvolveu sobre esse modo de pensar exaurindo daquela o seu telos. A plenitude, isto é, o acabamento da Filosofia ocorre em razão de somente a ela, assim, reservar-se a tarefa nada residual de pensar os modos de ser do ente humano e seus modos de lidar com os entes que ele também é e que não é. Mas a mudança enseja um novo lugar, um horizonte inexplorado e passível de ser questionado como abertura de pensamento na era da técnica.

A filosofia, enquanto metafísica, é uma experiência de pensamento que compreende a essência do homem como subjetividade, logo, o fim da filosofia, pode ser a abertura também para um outro modo do homem compreender a sua essência, a sua humanidade. Por isso, em Heidegger, o fim da filosofia, sendo uma possibilidade de abertura de pensamento é também uma possibilidade de abertura do homem para com sua essência. (SOUZA, 2005, f. 52).

O subjetivismo legado pela modernidade traduziu uma possibilidade do ser. O problema é que essa possibilidade foi eleita como totalidade e tanto mais objetiva se tem ela tornado, tanto mais oculto o sentido do ser tem se mantido. A relação sujeito-objeto está compreendida na história do ser, mas não se trata de sua possibilidade última e total. A Filosofia tem que se ver com o seu fim, uma vez que tornou estática a verdade do ser, aprisionou-lhe no ente, tendo estabelecido um primado para o sujeito e sua cisão com relação ao mundo. O fim da Filosofia, então, é a sua passagem para esse novo lugar, em que se torna presente a possibilidade de pensar o pensamento, questionar a questão, elaborar um novo projeto filosófico destinado ao ser. Trata-se da reunião do pensamento em suas possibilidades e modos de ser. 


\subsection{Da Finalidade}

Se a Filosofia, para os marxistas, encontra o seu fim por dissolver-se na práxis; se, para Wittgenstein, a Filosofia chegaria ao seu fim por cumprir o telos de realizar a terapia da linguagem; então, para Heidegger, a Filosofia, antes de haver-se com o seu fim enquanto término, há que se ver com uma fatal perda de sentido, que é, ao mesmo tempo, a sua reinvenção. A questão do ser como questão filosófica mesma fornece um novo lugar para a Filosofia, ao passo que redimensiona o seu fim, num sentido mais estrito, qual seja o de finalidade. Neste ponto residirá uma das contribuições deste trabalho à interpretação feita por Leão. Resgata-se, no sentido latino de fim, um complemento ao seu sentido antigo como lugar. Um novo lugar e uma nova finalidade: eis a tarefa do pensamento na era da técnica.

No Brasil, o juspositivismo ensejou, como na Europa, a barbárie. Sob as escusas de um positivismo estrito legitimou-se o totalitarismo, a ditadura civil-militar. A legalidade do direito posto foi plena em todo o tempo, embora o justo tenha ficado preterido, a situação ek-sistencial do povo brasileiro tenha sido esquecida. Instaurou-se, em plena força, o juspositivismo. No Estado, no Direito, na Academia e na Ciência. A modernidade nunca antes se nos tão atravessou. Mas, como picadas de lenhador, o pensamento cumpre o envio do ser. A fenomenologia existencial do direito, como crítica do direito brasileiro, permite a clareira, é suscetível à verdade, observa a expressão existencial peculiar desse povo de onde se havia instaurado o inautêntico juspositivismo. Ora, mas se o direito, como modo de ser do cuidado, pode alçar a níveis deficientes ou ontológicos desse existencial, do mesmo modo o é com o juspositivismo, pensamos. Aí está o método fenomenológico. Se é verdade que o positivismo, como o juspositivismo, traduzem, antes de tudo, um conceito de método, o qual se cumpre pela ida a posto, e, em consequência, ao direito posto; é igualmente verdade que a fenomenologia e, do mesmo modo, a fenomenologia existencial do direito, traduzem um caminho ontológico, hermenêutico, no sentido da coisa mesma, tomada em seu fenômeno. A fenomenologia, tão como a fenomenologia existencial do direito serão, portanto, a clareira na cotidianidade da técnica, em que a justeoria poderá, in fine, ocupar-se do mesmo, do oculto, em todas as positivações. Aí está a justiça. Aí está a cura. Aí está a verdade e seus ocultamentos.

Sob o horizonte da fenomenologia existencial do direito, acrescenta-se ao juspositivismo um novo lugar. Antes de haver-se, esse modo de pensar, com o seu término, no sentido de extinção, como querem os que advogam a ideologia pós-positivista; o juspositivismo se torna um museu de grandes novidades, de onde se podem (des)ocultar possibilidades múltiplas do ser jurídico. Mas não se trata da plenitude de uma tradição justeórica. Antes, do deslocamento, isto é, da mudança de um lugar para outro, do ente ao ser como tal. Irrompe um sentido de fim oculto às reflexões de Heidegger e da interpretação que de tais faz Carneiro Leão. Trata-se da noção de fim, enquanto finalidade.

Se o significado antigo da palavra fim remete à noção de lugar; o significado da palavra finalidade remete ao latim finalitas, que significa aquilo que pertence ao fim de alguma coisa, tendo como sinônimos, em língua portuguesa, as palavras alvo, objeto, objetivo, efeito, utilidade, propósito, intuito e destinação. O significado latino da palavra fim (finis) oculta igualmente o de finalidade, junto aos signos alvo e escopo.

Acredita-se, nessa esteira, que a finalidade que se (des)vela para o juspositivismo é, portanto, uma longa manus de sua verdade, isto é, a decorrência mais expressa de seu novo lugar. $\mathrm{O}$ propósito da pesquisa pelo justo concreto, enquanto pesquisa fenomenológica, pertence ao fim do juspositivismo, como anunciação de seu lugar na era da técnica. O juspositivismo chega ao seu fim, enquanto lugar, ao expressar a sua possibilidade autêntica como filosofia existencial do direito, ao que, a partir de agora propomos denominar de Juspositivismo ek-sistencial, desde um gesto de constatação teórica que fazemos. Até aí, estaria, de modo sofisticado, respondida a pergunta formulada por Streck (2010), responsável por instar a realização dessa pesquisa. Não se trata do 
fim do juspositivismo, enquanto término ou extinção, como quiseram as teorias críticas do direito, as quais tiveram em vista apenas a manifestação inautêntica do jurídico. O fim do juspositivismo, enquanto lugar, deixa ver a continuidade da história desse modo de ser do direito, a partir de uma interpretação fenomenológico-hermenêutica da justeoria.

Entretanto, o resgate do sentido latino da palavra fim, como finalidade, e a compreensão da noção de finalidade, também etimológica, como aquilo que se anuncia, isto é, está oculto no fim, anexada à compreensão antiga do fim, enquanto lugar, reúne o ser e o dever-ser sob a mesma estrutura binária da verdade (a-letheia). É o fím de um modo de pensar tradicional. Há um lugar de continuidade, mas de deslocamento e mudança nesse modo de pensar, a que convencionamos chamar de juspositivismo ek-sistencial. Desvela-se uma nova finalidade, que reside na pesquisa fenomenológico-hermenêutica pelo justo concreto. Não seriam, assim, três as tendências contemporâneas da jusfilosofia, como expôs Mascaro (2014). Mas, duas: a filosofia marxista do direito, que se constrói sob as críticas póstumas de Marx à manifestação inautêntica do juspositivismo e o juspositivismo, em sua história inautêntica, revelada pelos seus matizes eclético, estrito e ético, e em seu destino autêntico: o juspositivismo ek-sistencial.

\section{CONSIDERAÇÕES FINAIS}

Refletiu-se sobre os lugares pelos quais a jusfilosofia contemporânea passa no Brasil, nutrindo um ponto de vista dinâmico, a partir do sentido do juspositivismo. O juspositivismo, enquanto ideologia tendente à legitimação e à aceitação do direito posto e das instituições a ele atinentes, condensa, como se pode pontuar, as principais expectativas práticas dos juristas contemporâneos, sendo o modo de ser do jurídico mais próximo da cotidianidade. Discorreu-se, assim, a respeito dos juspositivismos, a partir de suas expressões eclética, estrita e ética, tendo, no construto heideggeriano da diferença ontológica ser-ente, o leitmotiv da investigação. Para tanto, elegeu-se, respectivamente, as reflexões de Reale, Kelsen e Dworkin. Compreendeu-se, com Reale, que o fenômeno jurídico dissolvido numa trindade dialética, esquece o sentido do ser, na medida em que se funda numa compreensão ôntica do ser-aí, como pessoa, valor-fonte, que compreende o ser como dever-ser, isto é, como realidade axiológica. Está apontado o sujeito kantiano, que cumpre uma síntese em favor do idealismo, além da tese das invariantes axiológicas sugerir uma metafísica ao modo do a-histórico, do ente. Com Kelsen, notou-se que uma compreensão pura do direito nada mais traduz que um idealismo objetivo, que toma o ser como ente, por elevar o direito posto ao fundamento último da jusciência. Finalmente, Dworkin deixa ver que, em sua compreensão moral do direito, o sujeito kantiano faz-se igualmente presente. O método da racionalidade prática dilui-se diante de um primado para este sujeito que, ao modo do juiz Hércules, fixa as condições da verdade, na busca por uma resposta correta, verdadeira, como adequação, instando o solipsismo. Os juspostivismos tradicionais, portanto, pensaram o mesmo. O ser foi tomado como ente, sendo, assim, esquecido.

Considerou-se, após, que numa compreensão do fenômeno jurídico que se paute nos pressupostos da ontologia fundamental, o direito passa a ser indagado em seu ser, de maneira que pode se traduzir em possibilidades autênticas e inautênticas. Os juspositivismos tradicionais traduziram uma possibilidade (in)autêntica do jurídico, um modo deficiente da história desse ser. Assim, se a metafísica dos entes passa a ser questionada desde sua base historiográfica, de modo que filosofia se tornou sinônimo de esquecimento do ser, uma compreensão ontológica mesma do direito permitiu que se pudesse compreender que a tradição jusfilosófica pensou o direito de modo essencialista, entificando-o, tal como fez a Filosofia com a questão do sentido do ser. O ser do direito passou a ser tido como sinônimo do direito posto, o ente "texto legislativo" passou a figurar como ser do jurídico, em prejuízo da diferença ontológica ser-ente. O fenômeno de entificação do ser jurídico foi, então, experimentado a partir de diferentes modos de ser, traduzindo juspositivismos ecléticos, estritos e éticos. 
Foram, em seguida, introduzidos os pressupostos da fenomenologia existencial do direito, oportunidade em que fora administrado o método antropofágico, subsumido ao método especulativo-hermenêutico. Os estudos de Pereira apontaram para o fato de a realidade de espoliação do povo brasileiro traduzir a expressão do se, do cotidiano do existente, tomado em sua impessoalidade. Tanto o autêntico, quanto o inautêntico compõem a historiografia desse ser que é o direito. Maman permitiu compreender, a partir do exame das estruturas do ser-aí, o destino do método fenomenológico, a sua aplicabilidade à pesquisa pelo justo. A Justiça torna-se o ser do jurídico, quando o existente pode ser-si-mesmo, assumindo sua ek-sistentia. A situação-limite pelo que passa a justeoria, na era da técnica permite que, tendo o juspositivismo tradicional se essencializado, em torno dos entes disponíveis, esquecendo o provimento do econômico, do político, do social; o jurídico possa se haver com o seu fim, mas reserva-se a possibilidade de se pensar o oculto na verdade conhecida. O juspositivismo assume um novo lugar. O juspensamento pode dobrar, à luz da linguagem, na clareira. A fenomenologia existencial do direito, no tocante ao pensamento jurídico brasileiro, passa a traduzir esse novo lugar a que alça o juspositivismo. Num sentido ontológico, ao direito mesmo, em seu fenômeno! Des-vela-se o juspositivismo em seu modo de ser autêntico. Este trabalho acrescenta à história do juspositivismo, a partir de uma constatação teórica, uma quarta dimensão: o juspotivismo ek-sistencial, que se perfaz pela interpretação fenomenológica da história do juspositivismo tradicional reunida aos estudos fenomenológico-existenciais do direito.

Em seguida, para elaboração da pergunta pelo ser do jurídico, foram discutidas as propostas heideggerianas a respeito do pensamento na era da técnica, sobretudo, a partir da exploração da plurivocidade da palavra fim, retomada em seu sentido grego. Perscrutou-se, a partir da polissemia da noção de fim, como término, plenitude e mudança, as possíveis contribuições heideggerianas para o trato com a situação-limite pelo que passa o juspositivismo em foros de virada linguística. Nesse momento, exsurge uma quarta acepção da palavra fim, tomada como finalidade. Essa nova acepção permite concluir, no tocante ao momento ek-sistencial pelo que passa o povo brasileiro, que a pesquisa fenomenológica pelo justo se traduz como um modo autêntico de juspositivismo, como uma possibilidade oculta de sua história, que ressoa no Direito brasileiro, com os estudos de Pereira e Maman, adjudicando ao direito a tarefa, isto é, a finalidade de realizar o cuidado. A finalidade é, como se consignou, aquilo que se oculta no fim e que se exprime como decorrência, como propósito, em última instância, como destino.

A compreensão polissêmica da noção de fim, permitiu, também, a elaboração de uma resposta singular da pergunta formulada por Streck a respeito dos limites do juspositivismo no tocante à virada linguístico-ontológica da filosofia. Neste quadrante da história, neste momento eksistencial, desoculta-se uma nova tarefa para o juspensamento, enquanto juspositivismo. A fenomenologia, tal como pensada por Heidegger a partir dos estudos de Husserl, caminha ao direito mesmo, em seu ser, não se restringindo às positivações, enquanto imagens entificadas do ser jurídico, mas lançando-se aos fenômenos, àquilo que está posto, tomado em sua presença. Por isso a proposta da fenomenologia existencial do direito se traduz como uma reunião à história do juspositivismo, como expressão de sua (in)autenticidade na era da técnica, em que se retoma o sentido grego de verdade. Esta pesquisa pretendeu tornar coeso este momento ek-sistencial e dá, assim, bases para a reformulação de um projeto prévio compreensivo inautêntico, a partir de ulteriores compreensões responsivas ativas, de modo que se constitui como um elo na cadeia enunciativa, sem guardar pretensões prometeicas de ser a última palavra.

Em suma instância, o juspositivismo, a partir da experiência instada pela virada linguístico-pragmática, é conduzido ao fim de seu modo de ser tradicional, como término, mas, ao mesmo tempo, é conduzido ao seu fim, enquanto lugar, a partir dos estudos fenomenológicoexistenciais, que visam à busca pelo direito que se põe, isto é, posto, a partir da noção de fenômeno. Inaugura-se a tendência do juspositivismo ek-sistencial. A reunião do sentido antigo de fim ao seu significado latino, permite compreender que, em foros de virada linguística, o que seria a fatal 
devastação de um modo de pensar se torna a sua última possibilidade, tendo se desocultado um novo fim, no sentido estrito de finalidade: a pesquisa fenomenológico-hermenêutica pelo justo concreto.

\section{REFERÊNCIAS}

ABBAGNANO, Nicola. Dicionário de filosofia. São Paulo: Mestre Jou, 1982.

ANDRADE, Oswald de. O manifesto antropófago. In: TELES, Gilberto Mendonça. Vanguarda européia e modernismo brasileiro: apresentação e crítica dos principais manifestos vanguardistas. Petrópolis: Vozes; Brasília: INL, 1976. Comentário e hipertextos: Raquel R. Souza (FURG).

BAKHTIN, M. Estética da criação verbal. São Paulo: Martins Fontes, 1992.

BOBBIO, Norberto et al. El positivismo jurídico. Madrid: Editorial Debate, 1993.

BOBBIO, Norberto. O Positivismo Jurídico: Lições de filosofia do direito. São Paulo: Ícone, 2006.

CAMARGO, M.M.L. Hermenêutica e argumentação: uma contribuição ao estudo do direito. Rio de Janeiro: Renovar, 2003.

CARNEIRO, Wálber Araújo. Hermenêutica heterorreflexiva. Porto Alegre: Livraria do Advogado, 2011.

COELHO, Luis Fernando. Apresentação. In: WARAT, Luíz Alberto. A pureza do poder: uma análise crítica da teoria jurídica. Florianópolis, Editora da UFSC, 1983.

DWORKIN, R. Levando os direitos a sério. São Paulo: Editora WMF Martins Fontes, 2002.

ECO, Umberto. Como se faz uma tese. São Paulo: Perspectiva, 1996.

HABERMAS, Jürgen. Direito e democracia: entre facticidade e validade. Rio de Janeiro: Tempo Brasileiro, 2003.

HEIDEGGER, M. Serenidade. Rio de Janeiro: Instituto Piaget, 2001.

HEIDEGGER, M. A Questão da Técnica. In:___. Ensaios e Conferências. Rio de Janeiro: Vozes, 2002a.

HEIDEGGER, M. Carta sobre el humanismo. Taurus, 1970.

HEIDEGGER, M. Carta sobre o humanismo. São Paulo: Centauro, 2005.

HEIDEGGER, M. O Fim da Filosofia e a Tarefa do Pensamento. In: . Os Pensadores. São Paulo: Nova Cultural, 1996a.

HEIDEGGER, M. O Que Quer Dizer Pensar. In: ___ _ Ensaios e Conferências. Rio de Janeiro: Vozes, $2002 \mathrm{~b}$. 
HEIDEGGER, M. Ser e tempo. Campinas: Editora da Unicamp; Petrópolis: Vozes, 2012 (Multilíngues de Filosofia Unicamp).

HUSSERL, Edmund. A crise da humanidade européia e a filosofia. Porto Alegre: Edipucrs, 1995.

JASPERS, K. A situação espiritual do nosso tempo. Lisboa: Moraes Editores, 1968.

KELSEN, Hans. Teoria pura do direito. São Paulo: Revista dos Tribunais, 2013.

LEÃO, Emmanuel Carneiro. Aprendendo a Pensar. Rio de Janeiro: Vozes, 2000. (vols. I e II).

LIMA, Priscila Sissi. O caminho do amor: a possibilidade existencial do amor em Heidegger e sua importância para a investigação do justo. 2015. Tese (Doutorado em Filosofia e Teoria Geral do Direito) - Faculdade de Direito, Universidade de São Paulo, São Paulo, 2015.

MAMAN, Jeannette Antonios. A via investigativa da filosofia do ser e o fenômeno jurídico. Revista da Faculdade de Direito, Universidade de São Paulo, v. 99, p. 477-482, 2004.

MAMAN, Jeannette Antonios. Ao encontro de Heidegger: a noção de ser-no-mundo. Revista da Faculdade de Direito, Universidade de São Paulo, v. 102, p. 611-615, 2007.

MAMAN, Jeannette Antonios. Fenomenologia existencial do direito. São Paulo: QuartierLatin, 2003a.

MAMAN, Jeannette Antonios. Língua e linguagem: os artifícios e a verdade jurídica. Revista da Faculdade de Direito, Universidade de São Paulo, v. 98, p. 503-508, 2003 b.

MAMAN, Jeannette Antonios. O direito como pesquisa do justo. Revista da Faculdade de Direito, Universidade de São Paulo, v. 103, p. 649-655, 2008.

MAMAN, Jeannette Antonios. O fenômeno jurídico como objeto de uma ontologia fundamental. Revista da Faculdade de Direito, Universidade de São Paulo, v. 94, p. 325-337, 1999.

MASCARO, Alysson Leandro. Filosofia do direito. São Paulo: Atlas, 2014.

MEDINA, Javier Garcia. Teoría integral del derecho en el pensamiento de Miguel Reale. Valladolid: Grapheus, 1995.

MIGNOLO, Walter D. Epistemic disobedience and the decolonial option: A manifesto. Transmodernity, v. 1, n. 2, p. 3-23, 2011.

PALMIER, Jean; TOWARNICKI, Frédéric de. Conversa com Heidegger. L'Express, Paris, n. 954, 20/26 oct. 1969.

PEREIRA, Aloysio Ferraz. Direito e dominação no horizonte da existência. Revista da Faculdade de Direito, Universidade de São Paulo, v. 75, p. 159-164, 1980 b.

PEREIRA, Aloysio Ferraz. Estado e direito na perspectiva da libertação: uma crítica segundo Martin Heidegger. São Paulo: Ed. Revista dos Tribunais, 1980a. 
PEREIRA, Aloysio Ferraz. Prefácio. In: MAMAM, J. A. Fenomenologia existencial do direito: crítica do pensamento jurídico brasileiro. São Paulo, SP: Quartier Latin, 2003.

REALE, Miguel. Invariantes axiológicas. Estudos avançados, v. 5, n. 13, p. 131-144, 1991.

REALE, Miguel. Teoria Tridimensional do Direito: situação atual. São Paulo: Saraiva, 1992.

ROSÁRIO, Luana Paixão Dantas do; et al. Apreciação crítica da noção de valor na teoria tridimensional do direito de Miguel Reale. Revista Brasileira de Direito, v. 12, n. 2, p. 180-192, 2016.

SANTOS, Boaventura de Sousa. Do pós-moderno ao pós-colonial. E para além de um e de outro. Travessias, n. 6/7, p. 15-36, 2008.

SÓFOCLES. Édipo Rei, Édipo em Colono, Antígona. Tradução de Mário da Gama Kury. Rio de Janeiro: Jorge Zahar, 1989.

SÓFOCLES. Édipo Rei/Antígona. Coleção obra prima de cada autor. São Paulo: Martin Claret, 2008.

SOUZA, Eduardo Boaventura de. O fim da filosofia em M. Heidegger. Dissertação (Programa de Pós-Graduação em Filosofia) - Universidade Federal da Bahia. Salvador, p. 81. 2005.

STRECK, Lenio Luiz. Aplicar a "letra da lei" é uma atitude positivista? Novos Estudos Jurídicos, v. 15, n. 1, p. 158-173, 2010.

WAHL, Jean. As filosofias da existência. Lisboa: Publicações Europa, América, 1962.

WARAT, Luis Alberto. A pureza do poder: uma análise crítica da teoria jurídica. Florianópolis: Editora da UFSC, 1983.

WARAT, Luis Alberto. Saber crítico e senso comum teórico dos juristas. Seqüência; Estudos Jurídicos e Políticos, v. 3, n. 5, p. 48, 1982. 